\title{
A bacterial group II intron encoding reverse transcriptase, maturase, and DNA endonuclease activities: biochemical demonstration of maturase activity and insertion of new genetic information within the intron
}

\author{
Manabu Matsuura, ${ }^{1,4}$ Roland Saldanha, ${ }^{1,4}$ Hongwen Ma, ${ }^{1,4}$ Herbert Wank, ${ }^{1,4}$ Jian Yang $^{1}$ \\ Georg Mohr, ${ }^{1,4}$ Stacey Cavanagh, ${ }^{2}$ Gary M. Dunny, ${ }^{3}$ Marlene Belfort, ${ }^{2}$ and Alan M. Lambowitz ${ }^{1,4,5}$ \\ ${ }^{1}$ Departments of Molecular Genetics, Biochemistry, and Medical Biochemistry, The Ohio State University, Columbus, Ohio \\ 43210-1292 USA; ${ }^{2} \mathrm{~N}$ ew York State Department of Health, Albany, N ew York 12201-0509 USA; ${ }^{3}$ Department of \\ Microbiology, University of Minnesota, Minneapolis, Minnesota 55455-0312 USA
}

The Lactococcus lactis group II intron LI.ItrB is similar to mobile yeast mtDNA group II introns, which encode reverse transcriptase, RNA maturase, and DNA endonuclease activities for site-specific DNA insertion. Here, we show that the Lactococcal intron can be expressed and spliced efficiently in Escherichia coli. The intron-encoded protein LtrA has reverse transcriptase and RNA maturase activities, with the latter activity shown both in vivo and in vitro, a first for any group II intron-encoded protein. As for the yeast mtDNA introns, the DNA endonuclease activity of the Lactococcal intron is associated with RNP particles containing both the intron-encoded protein and the excised intron RNA. Also, the intron RNA cleaves the sense-strand of the recipient DNA by a reverse splicing reaction, whereas the intron-encoded protein cleaves the antisense strand. The Lactococcal intron endonuclease can be obtained in large quantities by coexpression of the LtrA protein with the intron RNA in E. coli or reconstituted in vitro by incubating the expressed LtrA protein with in vitro-synthesized intron RNA. Furthermore, the specificity of the endonuclease and reverse splicing reactions can be changed predictably by modifying the RNA component. Expression in E. coli facilitates the use of group II introns for the targeting of specific foreign sequences to a desired site in DNA.

Key Words: Gene therapy; intron mobility; Lactococcus lactis; retrotransposition; ribozyme]

Received July 9, 1997; revised version accepted August 28, 1997.

Group II introns are mobile genetic elements with an extraordinary catalytic repertoire (Curcio and Belfort 1996; Pyle 1996). Their catalytic RN As promote RN A splicing and intron mobility reactions through their ability to act on both RNA and DNA substrates. Furthermore, they encode multifunctional proteins, which again act on both RN A and DN A to promote splicing and mobility. In addition to this unprecedented functional versatility, the splicing and mobility reactions of group II introns are of interest from an evolutionary perspective, because group II introns have been suggested to be progenitors of both spliceosomal introns (Sharp 1991;

4Present address: Institute of Cellular and Molecular Biology, Departments of Chemistry and Biochemistry, and Microbiology, University of Texas at Austin, Austin, Texas 78712 USA.

${ }^{5}$ Corresponding author.

E-MAIL lambowitz.1@osu.edu; FAX (614) 688-3555.
Michel and Ferat 1995) and non-LTR-retrotransposons (Zimmerly et al. 1995b).

Group II introns are characterized by a conserved secondary structure consisting of six double helical domains (Sal danha et al. 1993; Michel and Ferat 1995). Domains I and $V$ are minimal ly required for catalytic activity, whereas domain VI contains the branch point nucleotide. M obile group II introns encode open reading frames (ORFs), which are located primarily in the loop of domain IV, but in some cases extend upsteam to be contiguous with the 5' exon (Saldanha et al. 1993; Michel and Ferat 1995). Previous studies of group II intron mobility have focused on the yeast group II introns al 1 and al2, which characteristically move to cognate intronless alleles (homing) (Lazowska et al. 1994; Moran et al. 1995). The proteins encoded by al 1 and al 2 have been shown to have three activities: reverse transcriptase (RT) for intron duplication, maturase to promote splicing, and 
DNA endonuclease for site-specific cleavage of recipient alleles (Carignani et al . 1983; Kennell et al. 1993; Moran et al. 1994; Zimmerly et al. 1995a,b). The maturase activity, which has thus far only been shown genetically, presumably reflects that the protein binds specifically to the intron RNA and promotes or stabilizes formation of the catalytically active RN A structure (Lambowitz and Perlman 1990; Saldanha et al. 1993).

Remarkably, the studies with al 1 and al 2 showed that the intron-encoded DNA endonuclease activity, which initiates mobility, is associated with ribonucleoprotein (RNP) particles that contain both the intron-encoded protein and the excised intron RNA (Zimmerly et al. 1995a,b; Yang et al. 1996). Moreover, both the RN A and protein components function catalytically in DNA cleavage, with the intron RNA cleaving the sense strand of the recipient DNA by reverse splicing at the intron insertion site, and the intron-encoded protein cleaving the antisense strand at position +10 of the $3^{\prime}$ exon. After DNA cleavage, intron homing occurs by a target DNAprimed reverse transcription mechanism in which the $3^{\prime}$ end of the cleaved antisense strand is used as a primer for reverse transcription of either unspliced precursor RN A or the intron RNA that had reverse spliced into the sense strand of the recipient DN A (Zimmerly et al. 1995b; Eskes et al. 1997). The RT-mediated mobility of group II introns has been referred to as retrohoming (Curcio and Belfort 1996).

Further studies of the al 2 endonuclease showed that both the RNA and protein components contribute to recognition of the DNA target site (Guo et al. 1997). The DNA target site for sense-strand cleavage and reverse splicing extends from position -21 in the $5^{\prime}$ exon to +1 in the $3^{\prime}$ exon, with additional sequences between +1 and +10 required for antisense-strand cl eavage (positions refer to distance from the splice junction). A 13-nucleotide region of the DNA target site extending from position -12 to +1 is recognized primarily by base-pairing with the intron RNA. This region contains short sequence elements IBS1 and IBS2 (intron binding sites $\underline{1}$ and 2 ) and $\delta^{\prime}$, which base pair with complementary sequences EBS1 and EBS2 (exon binding sites 1 and 2 ) and $\delta$, located in different regions of domain I of the intron RNA. These base-pairing interactions had been shown previously to play a role in the RN A-catal yzed splicing of group II introns from precursor RN As and in the reverse splicing of group II introns into RNA substrates (Saldanha et al. 1993; Michel and Ferat 1995). The regions of the DNA target site flanking the IBS seqences are presumably recognized by the intron-encoded protein. In the case of al2, the protein primarily recognizes a subset of key nucleotide residues in the distal $5^{\prime}$ exon region of the DNA target site for reverse splicing and appears to promote DNA unwinding enabling base pairing of the intron RNA (Guo et al. 1997). Because recognition of the DNA target site involves base-pairing, it is possible to change the specificity of the endonuclease simply by modifying the RN A component (Eskes et al. 1997; Guo et al. 1997). The ability to design group II introns to target desired DNA sequences for site-specific cleavage and insertion could have widespread future applications in genetic engineering and gene therapy.

To fully exploit this approach as well as to further study the behavior of group II introns, it was desirable to express large amounts of the group II intron-encoded protein and RN P particles. Expression of active al 1 and al 2 proteins has proven difficult, however, in part because of differences in the genetic code and codon usage in yeast mitochondria. Recently, a number of group II introns have been found in several species of bacteria (Ferat and Michel 1993; Ferat et al. 1994; Knoop and Brennicke 1994; M ills et al. 1996; Mullany et al. 1996; Shearman et al. 1996). These introns utilize the standard genetic code and provide a seemingly desirable al ternative for expression and mechanistic studies. In most cases, however, splicing or mobility of the intron have not been reported to occur in vivo. One exception is the LI.ItrB intron, which was found in the putative relaxase gene (ItrB) of conjugative element pRS01 in Lactococcus lactis ML3 (Fig. 1A; Mills et al. 1996). The same intron (IntL) was found independently in the putative rel axase gene of the conjugative element inserted in the chromosome of $\mathrm{L}$. lactis 712 (Shearman et al. 1996). The intron is spliced in Lactococcus and gene disruption experiments suggest that the intron-encoded protein, denoted LtrA, is needed for splicing.

Here, we show that the intron-containing segment of the Lactococcus ItrB gene can be readily expressed in Escherichia coli, that the RN A precursor can be spliced efficiently, and that large quantities of active intron-encoded LtrA protein can be produced. The expressed protein forms functional RNP particles with the intron RNA and is shown to have RT, maturase, and endonuclease activities. Our results show the generality of the reaction mechanisms used by the yeast mtDNA group II introns. We al so show that the system is amenable to the targeting of foreign sequences to a specific site in DNA.

\section{Results}

Expression of the LtrA protein in E. coli

In initial experiments, we tested two constructs for expression of the LtrA protein in E. coli. The first construct, pLII, contains the LI.ItrB intron and flanking exons cloned behind the phage T 7 promoter in the expression vector pET-11a (Fig. 1A). This construct could potentially express both the intron RNA and the LtrA ORF, the latter with its own Shine-Dalgarno-like sequence for translation. The second construct, pLIIP, is a derivative of $\mathrm{pLI} 1$, which places the intron ORF immediately downstream of the phage T7 promoter and Shine-Dalgarno sequence of the vector. SDS-polyacrylamide gels stained with Coomassie blue showed that both constructs produced a protein that ran just below the 66-kD marker and was not produced by cells containing the vector pET-11a (Fig. 1B). This protein is approximately the size expected for expression of the entire ORF (70 kD), and we confirmed by sequencing that the 
A

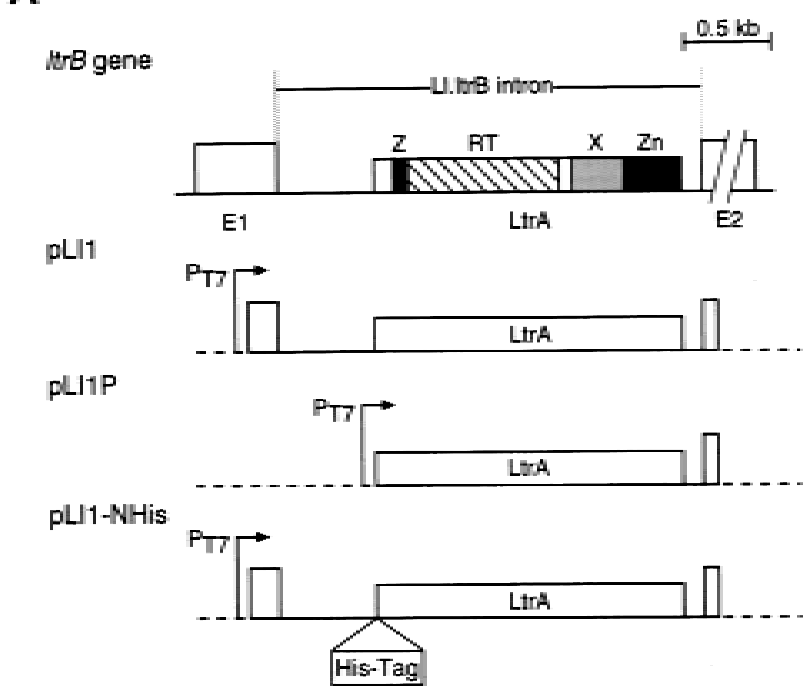

B

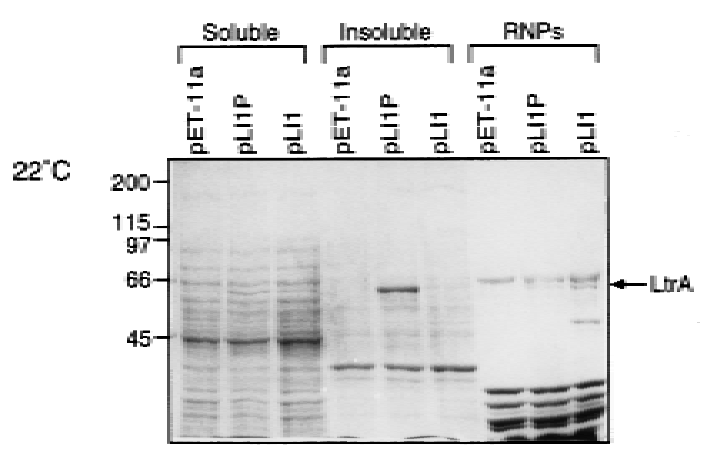

$37^{\circ} \mathrm{C}$

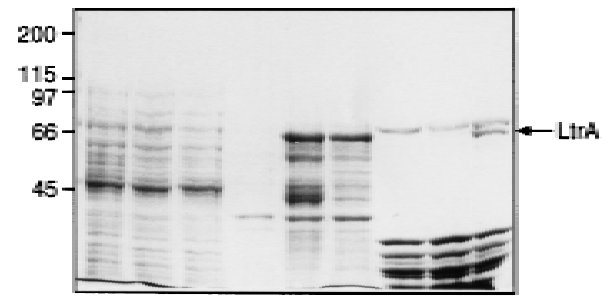

Figure 1. Expression of the LtrA protein in E. coli. (A) Diagram of the LI.ItrB intron and constructs pLII, pLIIP, and pLII-N His used for expression of the LtrA protein in E. coli. The protein domains shared by other group II intron ORFs are indicated (M ohr et al. 1993). Exons (E1 and E2) are open boxes, the intron is a line, and the LtrA ORF is a box within the intron. Vector sequences are indicated by broken lines. (B) SDS-PAGE of expressed proteins. Constructs were expressed in $\mathrm{E}$. coli $\mathrm{BL} 21(\mathrm{DE} 3)$ grown at $22^{\circ} \mathrm{C}$ or $37^{\circ} \mathrm{C}$, and proteins in the soluble, insoluble, and RNP fractions $\left(0.24 \mathrm{OD}_{260}\right.$ units) were analyzed by SDS-PAGE (Laemmli 1970) with a 3\% stacking gel and an $8 \%$ resolving gel. Shown is a Coomassie blue-stained gel. N umbers at left indicate molecular mass markers (kD).

protein produced by pLII has the expected amino terminus (not shown). The small discrepancy in apparent molecular mass likely reflects anomal ous migration of the basic LtrA protein relative to size markers.

Figure 1B compares the recovery of LtrA protein in soluble and insoluble fractions and in RNP particle preparations, which presumably contain LtrA protein bound to endogenous RNAs. LtrA protein from pLII, which coexpresses the intron and flanking exons, was $\sim 30 \%$ soluble in cells grown at $22^{\circ} \mathrm{C}$ and became more insoluble when expressed at $37^{\circ} \mathrm{C}$. The protein was readily detectable in RN P particle preparations at either temperature, but the yield of LtrA protein in RN P particles was two- to threefold higher at $37^{\circ} \mathrm{C}$. N otably, the LtrA protein from pLIIP, which lacks exon 1 and the $5^{\prime}$ segment of the intron, was largely insoluble at either $22^{\circ} \mathrm{C}$ or $37^{\circ} \mathrm{C}(70 \%$ and $>95 \%$ insoluble, respectively), and its recovery in RN P particles was reduced compared with the pLII construct. Thus, coexpression of the intron-containing RNA in pLII appears to improve the solubility of the LtrA protein and increase its recovery in RNP particles.

Optimization of LtrA synthesis was carried out with pLII-N His, a derivative of pLII in which $\mathrm{His}_{6}$ and Xpress (DLYDDDDK) epitope tags were linked to the amino terminus of the LtrA ORF (Fig. 1A). In cells grown at $22^{\circ} \mathrm{C}$, the yield of the tagged protein was $0.4-2 \mathrm{mg} / \mathrm{liter}$ of culture ( $2 \%-5 \%$ of the total protein), with $\sim 30 \%$ being soluble and $40 \%-90 \%$ of the soluble protein recovered in RNP particles (0.3-3 $\mu \mathrm{g}$ of LtrA protein $/ \mathrm{OD}_{260}$ ) (not shown). Based on the above experiments, pLII and its derivatives were used under the $22^{\circ} \mathrm{C}$ conditions to obtain large amounts of soluble protein, and under the $37^{\circ} \mathrm{C}$ conditions to obtain large quantities of active RN P particles.

\section{Assay of RT activity by use of exogenous substrates}

The RT activity of the expressed LtrA protein in the RN P particle preparations was first assayed with the artificial template-primer substrate poly(rA)-oligo(dT) $)_{18}$ in the presence of $\mathrm{RN}$ ase $\mathrm{A}$ to degrade the endogenous template RN A. Figure 2A shows that RN P particles from cells expressing pLII had high RT activity, whereas no activity was detected with RN P particles from cells harboring the vector pET-11a. RN P particles from cells expressing the pLI1-N His-tagged protein also had RT activity proportionate to the amount of LtrA protein in the preparations (not shown). As expected, the RT activity of the LtrA protein was abolished by a frameshift mutation after amino acid 124 of the LtrA ORF (pLII-FS) or by point mutations in the conserved YADD motif of the RT domain (pLI1-DD ). The YADD mutation did not substantially affect the recovery of LtrA protein in RN P particles (Fig. 2D). Notably, LtrA protein expressed from pLIIP, which lacks the $5^{\prime}$ segment of the intron, was detectable in RN P particles but had only low RT activity ( $10 \%$ of pLI1), which was less than expected for the amount of protein. Additional experiments showed that the RT activity of the LtrA protein is unstable under some conditions in the absence of the intron RNA (R. Saldanha and A.M. Lambowitz, unpubl.). These results suggest that binding to unspliced precursor and/or the intron RN A helps stabilize the LtrA protein in the active conformation, consistent with the findings above that coexpression of the full-length intron in pLII increases 
A

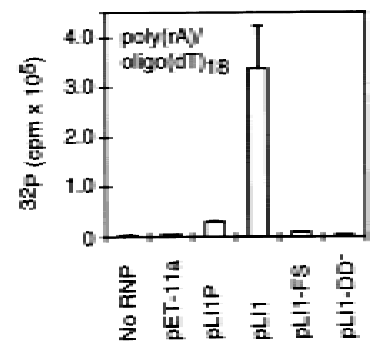

C

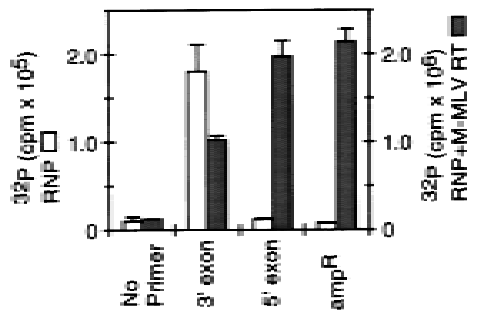

B

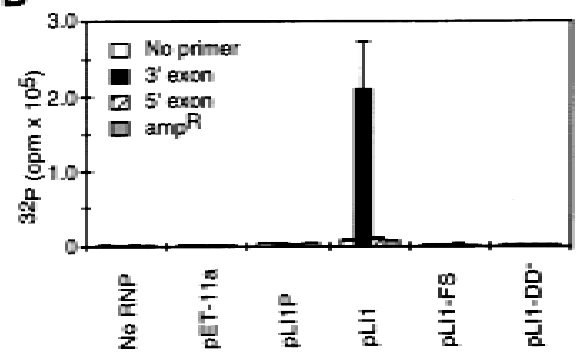

D

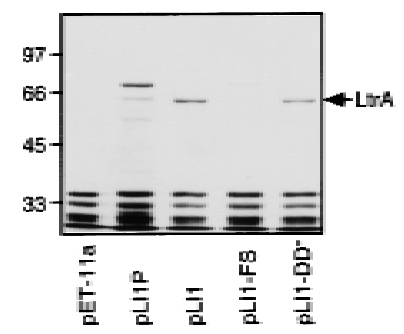

Figure 2. RT activity in RNP particle preparations from E. coli. (A) RT assays with

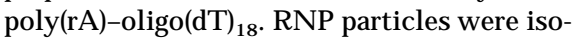
lated from cells grown at $37^{\circ} \mathrm{C}$, and RT activity was assayed, as described in M aterials and $M$ ethods. For pLIIP, the data shown are for cells grown at $22^{\circ} \mathrm{C}$, because no RT activity was detected in RNP preparations from cells grown at $37^{\circ} \mathrm{C}$. (B) Endogenous reverse transcription reactions in the RN $P$ particles. Reactions were carried out in the presence or absence of 20 pmoles of $3^{\prime}$ exon, 5' exon, or $a m p^{R}$ primers. (C) Control for accessibility of primers to endogenous RNA templates. Endogenous reactions with pLII RN P particles were carried out with different DNA primers in the presence (shaded bars) or absence (open bars) of M-MLV RT. (D) SDS-PAGE of RNP particle proteins. SDSPAGE was carried out as in Fig. 1, with 0.5 $\mathrm{OD}_{260}$ units of RNP particles. Numbers at left indicate molecular mass markers (kD). Error bars in the RT assays indicate standard deviations for three determinations. the solubility and RN P particle association of the LtrA protein.

RT activity with endogenous RNA templates in RNP particles

To identify the RNA species to which the LtrA protein is bound, RN P particle preparations were also assayed for RT activity with endogenous RNA templates, either al one or in the presence of DN A oligonucleotide primers complementary to different regions of the plasmid transcripts. Figure 2B shows that RN P particles from cells expressing pLII had high RT activity with endogenous RNAs in the presence of a primer complementary to the $3^{\prime}$ exon of the ItrB gene, whereas little or no RT activity was observed in the absence of this primer or with primers complementary to the $5^{\prime}$ exon or the $a m p^{R}$ gene of the vector. Controls for annealing and accessibility showed that all three primers could be utilized by Moloney murine leukemia virus (M-MLV) RT added to the RN P particle preparations (Fig. 2C). Similarly high levels of LtrA RT activity were observed with $3^{\prime}$ exon primers having $3^{\prime}$ ends at different positions: E2 +15 (Fig. 2B), E2 +10, or E2 +20 (not shown). $\mathrm{N}$ o endogenous RT activity was detected with any primer in RNP particles from cells containing the vector or expressing the mutant $\mathrm{FS}$ or $\mathrm{DD}^{-}$proteins, and only minimal activity ( $<1 \%$ pLI1) was detected in cells containing pLIIP, which expresses the LtrA protein in the absence of intact intron RNA (Fig. 2B). We confirmed that the endogenous RT activity of pLII RNP particles in the presence of the $3^{\prime}$ exon primer was sensitive to pretreatment with RN ase $A$ and insensitive to actinomycin D (61\% of control values at $20 \mu \mathrm{g} / \mathrm{ml}$ ), as expected for an RT with an RNA template.

The finding that endogenous RT activity in the $\mathrm{pLI} 1$
RN Ps is detected only with the $3^{\prime}$ exon primers suggests that the LtrA protein binds to unspliced precursor RN A near the $3^{\prime}$ end of the intron. In accord with this location, Southern hybridizations showed that ${ }^{32} \mathrm{P}$-labeled cDN As synthesized from endogenous RNAs in the presence of the $3^{\prime}$ exon primer hybridized predominantly to the Lactococcus intron (not shown). The finding that the RT is associated with unspliced precursor RNA is expected if the LtrA protein functions in RNA splicing. Furthermore, the finding that the LtrA protein is positioned to initiate reverse transcription in the $3^{\prime}$ exon is similar to findings for the yeast al 2 intron (Kennell et al. 1993; Zimmerly et al. 1995b; S. Zimmerly and A.M. Lambowitz, unpubl.).

The LI.ItrB intron is spliced in Escherichia coli and requires the LtrA protein

To determine if the intron in the construct pLII is spliced in Escherichia coli, Northern hybridization analysis was performed (Fig. 3). The precursor RN A was detected with a $3^{\prime}$ splice site probe (probe A), and the ligated exons with a splice junction probe (probe B). An in vitro (IV) spliced precursor RNA was included for comparison (lanes 7). Precursor processing and exon ligation in vivo began within $0.5 \mathrm{hr}$ after the induction of synthesis of the Lactococcal RN A and persisted for $4 \mathrm{hr}$. The disappearance of precursor at later times likely reflects both splicing and RN A turnover, as evidenced by the RNA fragments detected with probe $A$ and by the extensive degradation of the intron observed in blots hybridized with intron-specific probes (not shown).

To circumvent problems associated with rapid RNA turnover in E. coli, the accuracy of splicing and its dependence on the LtrA protein were assessed by primer extension assay. The precision of $5^{\prime}$ splice-site cleavage 

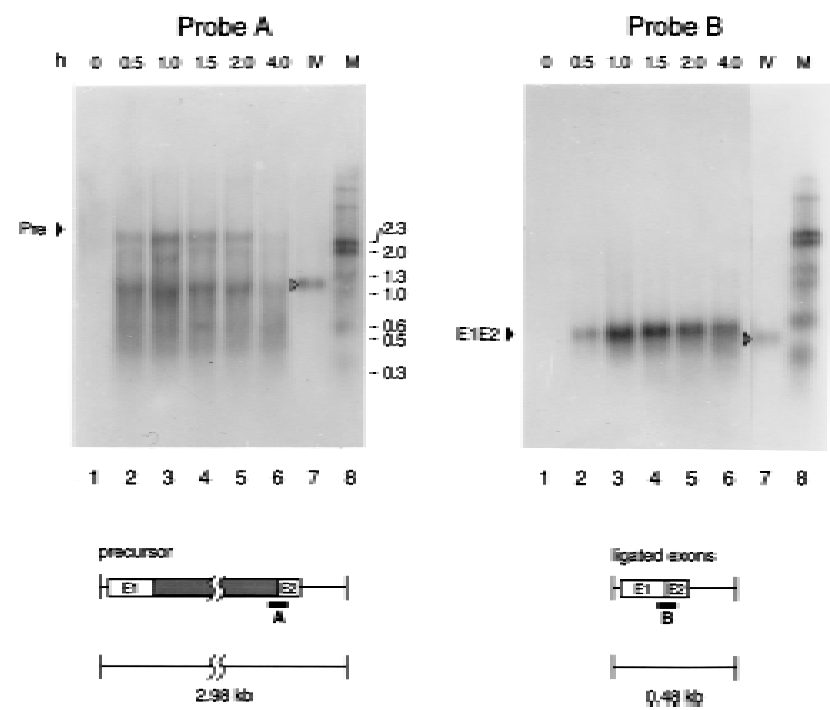

Figure 3. RNA splicing in E. coli. Northern hybridizations were performed with RNA extracted from E. coli 0 to $4 \mathrm{hr}$ after induction of transcription from plasmid pLII (lanes 1-6). Oligonucleotide probe $A$ hybridizes to the $3^{\prime}$ splice site of the precursor RNA, whereas probe $B$ hybridizes to the splice junction of the ligated exons. (Lanes 7) RN A transcribed from pLI2$\triangle O R F$ and self-spliced in vitro (IV). The hybridization to selfspliced RNA shows the specificity of the probes and provides RN A size markers (precursor, $1.25 \mathrm{~kb}$, ligated exons $0.35 \mathrm{~kb}$ ). (Lanes 8) DNA size markers, with sizes $(\mathrm{kb})$ indicated to the right. In the schematic below, exons are $\square$, the intron is a shaded box, and vector sequences are represented by a line. Probes are shown as black bars.

was determined by performing CDNA synthesis with an intron primer (primer 1; Fig. 4A,B). A CDNA corresponding precisely to the $5^{\prime}$ end of the intron, as determined from parallel DNA sequencing lanes (not shown), was observed within $0.5 \mathrm{hr}$ of induction of pLI1 transcription, along with a doublet corresponding to $5^{\prime}$ ends of unspliced precursor RNAs. Ligated exon RNAs were detected as a corresponding CDNA doublet with an exon 2 primer with the same time course of appearance as the excised intron (Fig. 4A,B). The longer $5^{\prime}$ exon end corresponds to the predicted transcription start site at the $\mathrm{T} 7$ promoter of pLI1, whereas the shorter $5^{\prime}$ end coincides with the junction of vector and Lactococcal sequences and may reflect the creation of a new transcription start or processing site.

The dependence of splicing on the LtrA protein was assessed by use of the construct pLI2- $\triangle O R F$, which contains an intact catalytic RNA, but has a deletion corresponding to amino acids $40-572$ of the LtrA coding sequence in the loop of domain IV. In this case, the RNA preparations still showed the precursor doublet, but the intron and ligated exon bands were completely absent, suggesting that the expressed LtrA protein is required for splicing of the Lactococcal intron in E. coli (Fig. 4A,B). Additional experiments showed that splicing was also inhibited in cells expressing the frameshift mutant pLI1FS or LtrA proteins with point mutations in the putative maturase domain (domain $X$; not shown). Sequencing of the ligated exon product via RT-PCR with primers P3 and P4 (see Fig. 4B) confirmed that splicing had occurred correctly (data not shown).

Protein-dependent splicing of the LI.ItrB intron in vitro

In vitro splicing by the expressed LtrA protein was investigated by use of ${ }^{32} \mathrm{P}$-labeled precursor RN A synthesized from the construct pLI2- $\Delta \mathrm{ORF}$, which lacks most of the intron ORF (Fig. 5). This transcript self-spliced in high salt (HS) reaction medium containing $500 \mathrm{~mm}$ $\mathrm{NH}_{4} \mathrm{Cl}$ and $50 \mathrm{~mm} \mathrm{MgCl}$ to yield ligated exons and intron lariat (lanes 1-3). Under low salt (LS) conditions (100 $\mathrm{mm} \mathrm{N} \mathrm{aCl}$ and $10 \mathrm{~mm} \mathrm{M} \mathrm{gCl}$ ), the transcript did not self-splice (lanes 4-6), presumably reflecting the inability of the intron to fold into the catalytically active structure under these conditions, but splicing could be induced by the addition of micrococcal nuclease ( $\mathrm{M} \mathrm{N}$ ase)digested RNP particles containing LtrA protein expressed from pLII (lanes 7-9). In contrast, no splicing was detected under these conditions with RN P particles from cells containing the vector pET-11a (Ianes 10-12), or from cells expressing the frameshift mutant (pLI1-FS; lanes 13-15), or two other LtrA mutant proteins having missense mutations in the putative maturase domain (domain X; not shown). We confirmed by RT-PCR and sequencing that exon ligation with the pLI1 protein had occurred correctly (not shown). For unknown reasons, the ligated exon band appeared as a doublet in the selfsplicing reaction, but was more homogeneous in the protein-assisted reaction (cf. lanes 2 and 3 with lanes 8 and 9). In some lanes, incubation with the RN P particles resulted in increased nonspecific degradation of the ${ }^{32} \mathrm{P}$ labeled RN A, presumably as a result of E. coli nucleases. The protein-dependent splicing reaction was not stimulated by addition of ATP (not shown). In kinetic experiments, the initial rates of self-splicing and protein-dependent splicing were $3.2 \pm 0.6 \times 10^{-4} / \mathrm{sec}$ and $2.9 \pm 0.8 \times$ $10^{-3} / \mathrm{sec}$, respectively, comparable to rates of self-splicing of well-studied yeast mtDNA group II introns $\left(6.8 \times 10^{-3}\right.$ to $6.3 \times 10^{-4} / \mathrm{sec}$; Daniels et al. 1996; Costa et al. 1997). These results constitute the first biochemical demonstration of the maturase activity of a group II intron-encoded protein.

\section{Characterization of DNA endonuclease activity}

To assay DNA endonuclease activity of the LI.ItrB intron, RN P particle preparations from cells expressing the LtrA protein were incubated with small (129 bp) labeled DN A substrates that contain the intron insertion site at the junction of exons 1 and 2 of the ItrB gene. In Figure $6, A$ and $B$, the DN A substrates were generated by PCR with $5^{\prime}$ end-labeled primers to separately label each of the two DNA strands, and the products were anal yzed in denaturing polyacrylami de gels to detect the 5 ' fragment of each strand. The RNP particles from cells expressing $\mathrm{pLI} I$ cl eaved each strand of the DNA substrate at a single major site (Fig. 6, lanes 1), whereas these cleavages were not detected with RNP particles from cells expressing 
A

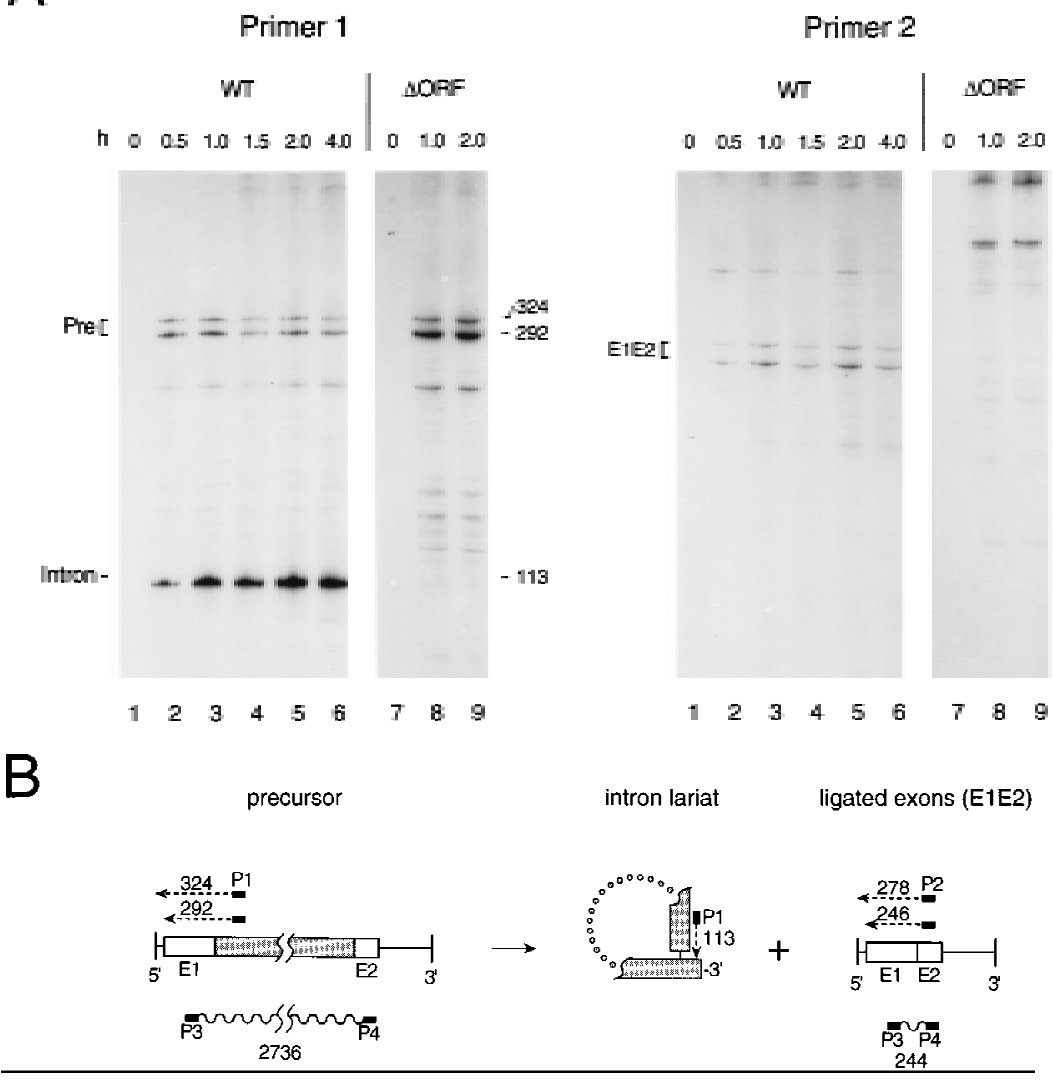

Figure 4. RNA splicing is accurate in E. coli. (A) Primer extension analysis. RN As extracted from E. coli at the indicated times after induction of transcription from plasmids pLI1 (lanes 1-6) or pLI2- $\mathrm{ORF}$ (lanes 7-9) were reverse-transcribed with intron-specific primer 1 or exon 2-specific primer 2. The cDN A bands, of lengths indicated in nucleotides to the right of each panel, correspond to precursors (Pre) and intron lariat for primer 1 , and ligated exons (E1E2) for primer 2. (B) Schematic of RNAs, CDNAs, and PCR products. RNAs are depicted as in Fig. 3, cDNA extension products are shown as broken lines, PCR products as wavy lines, and primers as black bars. the truncated FS protein (lanes 7) or containing the vector al one (lanes 6). Alignment with the sequencing ladder showed that the sense strand was cleaved precisely at the intron insertion site, and the antisense-strand was cleaved at position +9 of exon 2 (Fig. $6 A, B, E$ ). The sense strand cleavage is at the same position as for the yeast al 1 and al 2 introns, whereas the antisense-strand cleavage site is one nucleotide closer to the intron insertion site (cf. Zimmerly et al. 1995b; Yang et al. 1996). In the reaction with the $5^{\prime}$ sense-strand-label ed substrate, the pLI1 RNP particles gave an additional high molecular weight band that migrated above the substrate and likely results from compl ete reverse spli cing of the intron RN A into the sense strand of the DN A substrate (Fig. 6A, Iane 1; see schematic Fig. 6D). This band disappeared after RN ase digestion with the concommitant appearance of a band one nucleoti de longer than the major sense-strand cleavage product, presumably caused by incomplete removal of ribonucleotides from the fully reverse spliced product (lane 2). Approximately $5 \%$ of the DNA substrate was cleaved by the pLII RNP particles in these experiments.

As expected for an RNP complex containing the intron-encoded protein and the intron RNA, the endonuclease activity of the Lactococcal intron was inhibited by pretreatment with either RNase or protease (Fig. $6 \mathrm{~A}, \mathrm{~B}$, Ianes 4,5), and RN $\mathrm{P}$ particles from cells containing pLIIP, which express LtrA protein in the absence of in- tact intron RN A, had no detectable endonuclease activity (lane 8). In other experiments, the endonuclease activity was inhibited both by a mutation that deletes the $\mathrm{Zn}$ domain of the intron-encoded protein ( $\Delta \mathrm{Zn} ; \Delta$ amino acids 491-599) and by a mutation ( $\Delta D 5)$ that deletes domain $\mathrm{V}$ of the intron RNA but continues to synthesize active intron-encoded RT protein (H. Ma, M. Matsuura, and A.M. Lambowitz, unpubl.), mirroring results for the yeast mtDN A introns (Zimmerly et al. 1995a,b). Furthermore, a smaller carboxy-terminal truncation ( $\Delta$ ConZn; $\Delta$ amino acids 543-599) that deletes just the conserved $\mathrm{Zn}^{2+}$-finger-like and endonuclease motifs continued to carry out the RNA-catalyzed sense-strand cleavage but showed no detectable antisense-strand cleavage, which is presumably catalyzed by this region of the LtrA protein (H. Ma, M. Matsuura, and A.M. Lambowitz, unpubl.).

Endonuclease assays with internally label ed DN A substrates to detect all of the DNA fragments provided further evidence that the sense-strand cleavage occurs by reverse splicing. The 73-nucl eotide product, corresponding to the $3^{\prime}$ exon fragment of the sense-strand, was detected in polyacrylamide gel s only after RN ase digestion, suggesting attachment to a large RNA as expected for either partial or complete reverse splicing (Fig. 6C,D). Furthermore, with the internally labeled substrate, high molecular weight, RN ase-sensitive bands corresponding to both partially and fully reverse spliced products could 


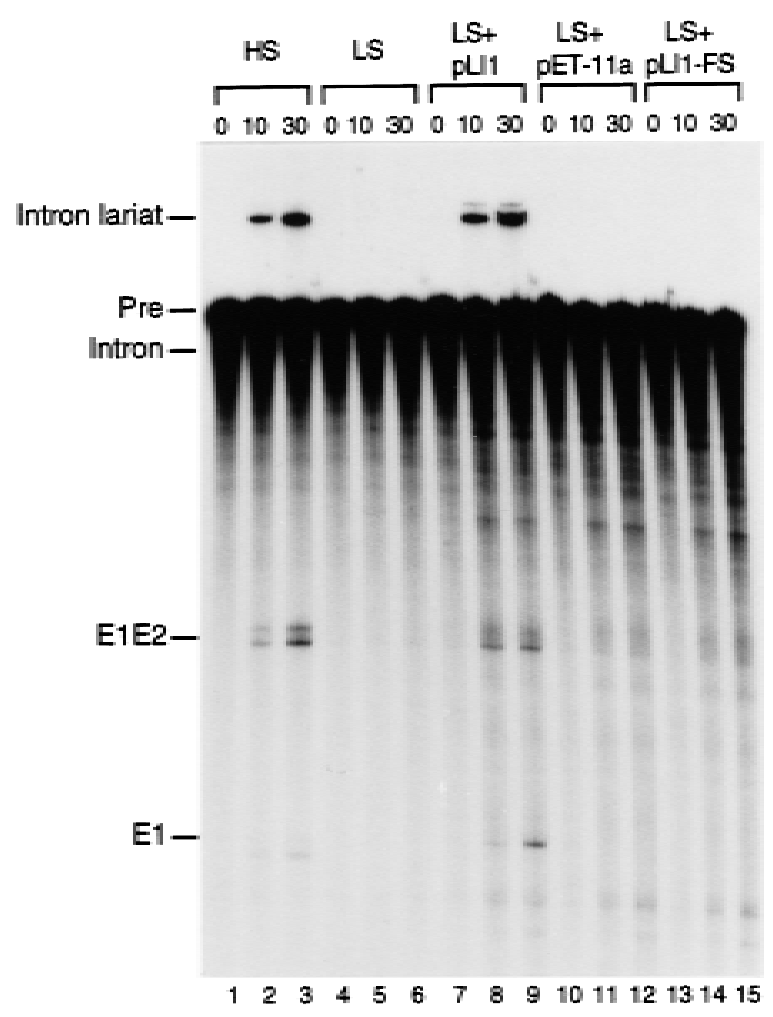

Figure 5. Protein-dependent in vitro splicing of the LI.ItrB intron. ${ }^{32} \mathrm{P}$-Labeled in vitro transcript $\mathrm{pLI} 2-\Delta \mathrm{ORF} / \mathrm{EcoRI}$ was incubated for 0,10 , or 30 min under high salt (HS) (lanes 1-3) or Iow salt (LS) (lanes 4-15) conditions (see $M$ aterial s and $M$ ethods) in the presence or absence of $\mathrm{M} \mathrm{N}$ ase-digested RN P particles $(0.1$ $\mathrm{OD}_{260}$ unit) from $\mathrm{E}$. coli expression strains grown at $37^{\circ} \mathrm{C}$. The products were analyzed in a denaturing $4 \%$ polyacrylamide gel, which was dried and autoradiographed. (Lanes 1-6) Precursor RNA incubated in the absence of RNP particles; (lanes 7-15) precursor RNA incubated under LS conditions with MNasedigested RN P particles from E. coli expressing pLII (lanes 7-9), pET-11a (lanes 10-12), or pLI1-FS (lanes 13-15). (Pre) Unspliced precursor RN A; (E1E2) ligated exons; (E1) exon 1.

be detected migrating above the substrate band in the polyacrylamide gels (see below for explanation of bands).

\section{Sense-strand cl eavage occurs by reverse splicing}

To further characterize the putati ve reverse spliced products, the RNP particle preparations were incubated with small ${ }^{32}$ P-labeled DNA substrates, and the products were analyzed in an agarose gel. As shown in Figure 7A, high molecular weight $(>0.5 \mathrm{~kb})$ products were detected with RN P particles from cells expressing pLII (lane 2), but not with RNP particles from cells expressing the vector pET-11a (lane 9), pLI1-FS, which has the frameshift mutation, or pLIIP, which produces LtrA protein but not intact intron RN A (lanes 10,11). The major products of $\sim 1 \mathrm{~kb}$ are shorter than expected, presumably caused by degradation of the intron RNA, as observed in the $\mathrm{N}$ orthern hybridizations (not shown). Small amounts of larger products, including some of the size expected for full-length intron RNA ( $2.5 \mathrm{~kb}$ ), were al so detected in darker exposures. The identity of a smaller band that migrates just above the DNA substrate is not known. The reverse splicing reaction was inhibited by pretreating the RN P particles with RN ase A or protease (Fig. 7, lanes 7 and 8 ), and the products were sensitive to RN ase, alkali, S1 nucl ease, and DN ase I, as expected (lanes 3-6). The residual light band with DNase I presumably re flects short ${ }^{32} \mathrm{P}$-label ed DN A fragments that remain attached to the intron RNA.

Assays with DNA substrates labeled to similar specific activity at each of four termini showed that the reverse spliced products were detected only with DNA substrates label ed at the $5^{\prime}$ or $3^{\prime}$ ends of the sense strand (Fig. 7B). Both major products that were detected with internally labeled DNA substrate (lane 1) were also detected with the $3^{\prime}$ sense-strand-label ed substrate (lane 3 ), indicating that they contain intron RNA linked to $3^{\prime}$ exon DNA. The additional minor product detected with the $5^{\prime}$ sense-strand-labeled DNA presumably corresponds to the fully reverse spliced product in which the intron RNA is also attached to the $5^{\prime}$ exon DNA. Cloning and sequencing of the intron-exon junctions of the putative fully reverse spliced product by RT-PCR confirmed that the intron RNA had accurately reverse spliced into the DNA target site (not shown).

As noted above, the predominant reverse spliced products are shorter than expected because of degradation of the intron RNA, which likely occurred in E. coli. Estimates of the sizes of RN A fragments attached to the $5^{\prime}$ and 3'-exon DN As in polyacrylamide gels (Fig. 6C) suggests that the fragments result from cl eavages in the loop of domain IV at approximately at positions 850 and 2360, respectively. The cleavages at these locations apparently leave the catalytic core of the intron intact to catalyze reverse splicing.

\section{Changing endonucl ease specificity by modifying EBS1}

In the cases of al 1 and al2, the specificity of the intron endonuclease could be changed by modifying the intron's EBS sequences, which base-pair with the IBS sequences in the DN A target site (Eskes et al. 1997; Guo et al. 1997). To test whether this is also the case for the LI.ItrB intron, we made a modified intron expression construct pLI1-EBS1-6C, which has a $G \rightarrow C$ change at EBS1 position -6 (i.e., the intron nucleotide that basepairs with E1-6 of IBS1). The putative IBS1/EBS1 interactions for the wild-type and modified intron are shown in Figure 8D (see Mills et al. 1996 for identification of the LI.ItrB intron's EBS and IBS sequences). The construct expressing the intron with the modified EBS1 sequence al so contained a complementary change (E1-6G) in IBS1, enabling the modified intron to splice efficiently in $\mathrm{E}$. coli. RNP particles from cells expressing the modified intron had wild-type levels of RT activity (not shown).

Figure 8 shows endonuclease $(A, B)$ and reverse splicing (C) assays comparing the target-site specificity of RN P particles containing the wild-type (EBS1-6G) and modified (EBS1-6C) introns. In both assays, the wild-type intron was active with the wild-type DNA target site, but 

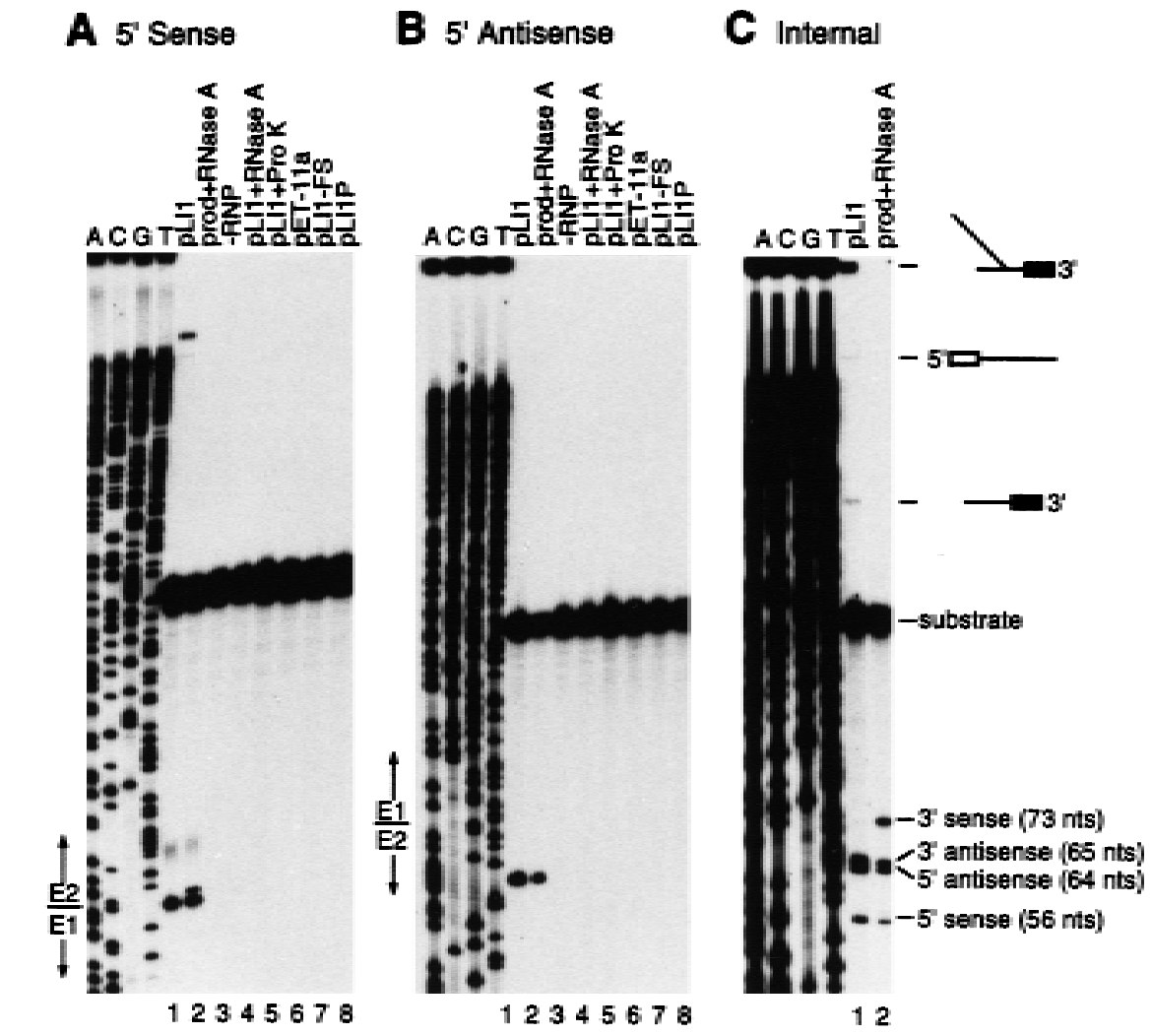

D
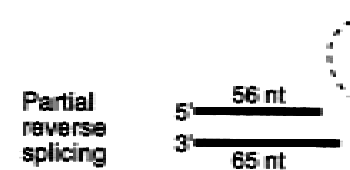<smiles>c1ccccc1</smiles>

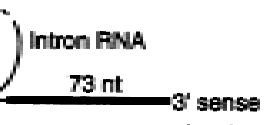

Complete
reverse
splicing
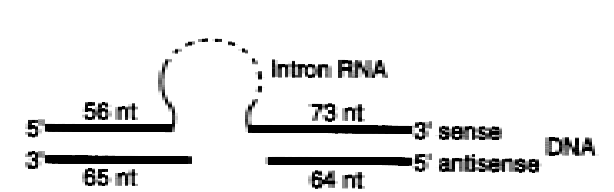

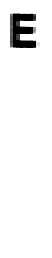

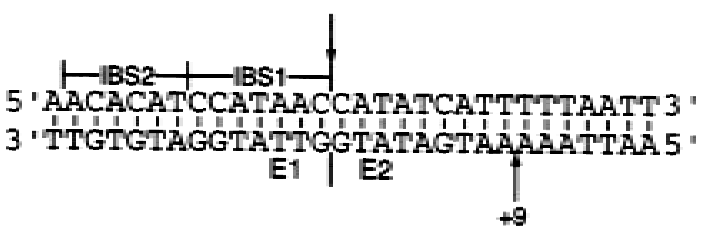

Figure 6. Assay of DNA endonuclease activity with E1E2 DN A substrates. (A,B) Endonucl ease assays with $5^{\prime}$ sense and 5' antisensestrand-labeled substrates, respectively. RNP particles $\left(0.025 \mathrm{OD}_{260}\right.$ unit) from the indicated strains grown at $37^{\circ} \mathrm{C}$ were incubated with the label ed DN A substrates, and the cleavage products were analyzed in a denaturing $6 \%$ polyacrylamide gel, al ongsi de sequencing ladders obtai ned from pLHS with the same 5'-end-label ed primer used to generate the substrate. (Lanes 1) pLI1 RN P particles; (lanes 2) cleavage products from the reaction of lane 1 incubated with RN ase A; (lanes 3) DNA substrate incubated in the absence of RN P particles; (lanes 4,5) pLII RN P particles pretreated with RN ase A or proteinase K; (lanes 6-8) RN P particles from cells containing the vector pET-11a, pLII-FS, and pLI1P, respectively. The diffuse bands above the major sense strand cleavage product were not detected with internally labeled DN A substrate (see below) and are presumably an artifact of the 5 '-end-labeled substrate. (C) Endonuclease assays with internally labeled DNA substrate. (Lane 1) pLII RN P particles; (lane 2) cleavage products from the reaction of lane 1 incubated with RN ase A, as above. (D) Schematic showing the products expected for partial and complete reverse splicing of the LI.ItrB intron into the DNA substrate. The dashed line depicts the cleaved region of the intron RN A (see Fig. 7). (E) Sequence of the LI.ItrB target site showing the location of the cleavage sites (arrows) on the sense (top) and antisense (bottom) strands.

not with a modified DNA target site that has a $\mathrm{C} \rightarrow \mathrm{G}$ change resulting in mispairing at E1-6 (lanes 1,2). In contrast, the modified intron no longer cleaved the wildtype target site but did cleave the modified target site that has the complementary change, C $\rightarrow$ G, at E1-6 (lanes 3,4). Thus, a single nucleotide change in IBSI of the target DNA was sufficient to almost totally block DNA endonuclease and reverse splicing activity, but these activities could be restored by introducing the compensatory change in the intron's EBS1 sequence.

Reconstitution of endonuclease activity with in vitro-synthesized intron RNA

To overcome the difficulty of preparing RN P particles with intact intron RNA from E. coli, we reconstituted 
Figure 7. Reverse splicing of the LI.ItrB intron into the E1E2 DNA substrate. (A) Reverse splicing reactions with internal ly label ed DN A substrate. RNP particles $\left(0.025 \mathrm{OD}_{260}\right.$ unit) from cells grown at $37^{\circ} \mathrm{C}$ were incubated with the 129-bp ${ }^{32} \mathrm{P}$-labeled E1E2 DNA substrate $(150,000 \mathrm{cpm}, \sim 125$ fmoles). The products were denatured with glyoxal and analyzed in a $1 \%$ agarose gel. (Lane 1) DN A substrate incubated in the absence of RN P particles; (lane 2) DNA substrate incubated with RNP particles from cells expressing pLI1; (lanes 3-6) reverse spliced products of pLII RN P particles treated with RN ase A, alkali, S1 nuclease, or DN ase I; (lanes 7,8) pLI1 RN P particles pretreated with RN ase $A$ or proteinase $K$ prior to reverse splicing (see $M$ aterials and Methods); (lanes 9-11) DNA substrate incubated with RNP particles from cells containing pET-11a, pLI1-FS, and pLIIP, respectively. (B) Reverse splicing reaction with E1E2 DNA substrates labeled separately at each of the four termini. pLII RNP particles were incubated with $5^{\prime}$ - or $3^{\prime}$-end-labeled DNA substrates $(150,000 \mathrm{cpm} ; \sim 250$ fmoles of $5^{\prime}$-end-labeled substrates and $\sim 200$ fmoles of $3^{\prime}$-end-labeled substrates), and the products were analyzed as above. N umbers to the left indicate DNA size markers (kb).
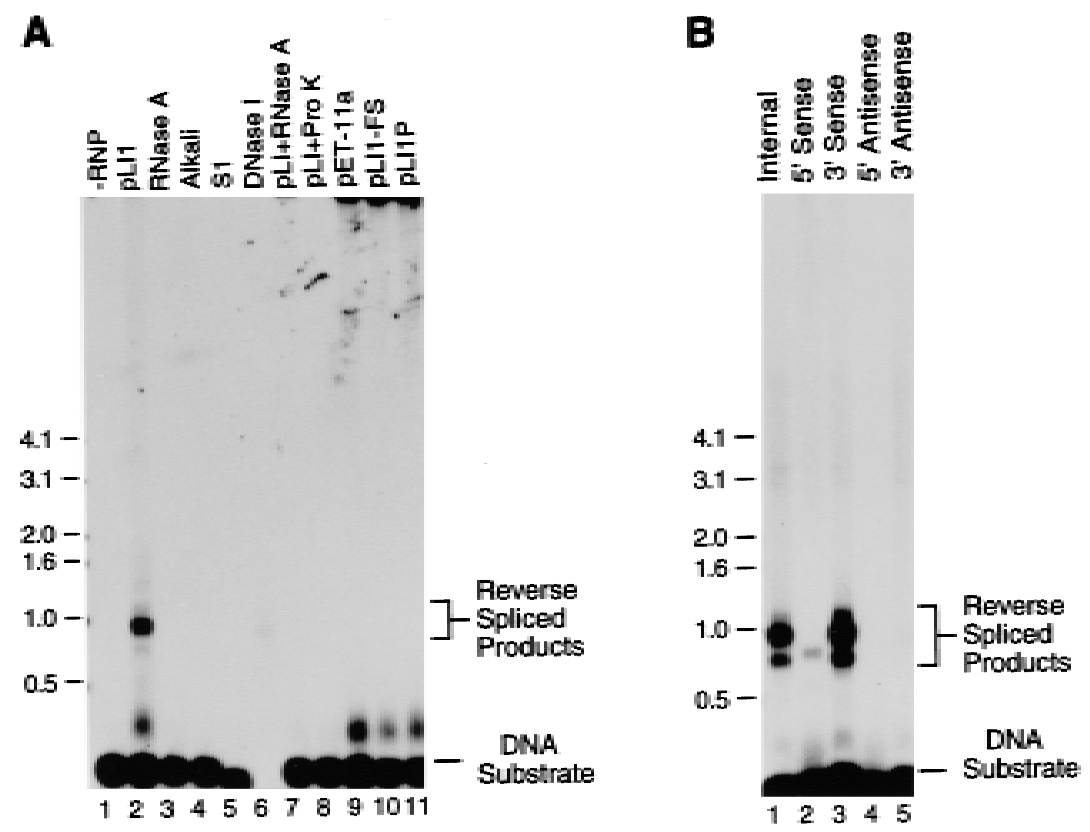

RN P particles with LtrA protein and in vitro-synthesized intron RNA. The RNA component for reconstitution was obtained by self-splicing the in vitro transcript pLI2$\triangle \mathrm{ORF} / \mathrm{BamHI}$, which contains the 1-kb intron-derivative with a deletion in the intron ORF. The in vitro transcript was incubated under high salt conditions, in which the intron splices efficiently in the absence of the LtrA protein (see above), and reconstitution was performed by incubating the spliced products with LtrA protein released from pLII RN P particles by MN ase digestion.

Figure 9A shows that the reconstituted RNP particles reverse spliced efficiently into ${ }^{32} \mathrm{P}$-labeled DNA substrate containing the Lactococcal intron target site to yi el d products of $\sim 1 \mathrm{~kb}$, the size expected for insertion of the intact $\triangle O R F$ intron RNA (lane 4). Reverse-spliced products were not detected with either the in vitro spliced RNA or the RN P protein fraction alone (lanes 2 and 3). The M N ase-digested RN P particle fraction by itself gave a smal ler band that results from reverse splicing of incompletely digested endogenous intron RNA. As expected, reverse splicing by the reconstituted RN P particles was inhibited by pretreatment with either RN ase or protease (lanes 5 and 6), indicating that both the RN A and protein components are required. Additional experiments with $5^{\prime}$ and $3^{\prime}$ end-labeled DNA substrates showed that the reconstituted RNP particles produced predominantly partially reverse spliced product with only a small proportion ( $<1 \%$ ) of fully reverse spliced product, as found above for native RN P particles (not shown). Both of the two major bands observed with internally labeled substrate (Fig. 9A) presumably corre- spond to partially reverse spliced products, possibly containing different conformers of intron lariat RN A, as appears to be the case for the yeast mtDNA introns (Zimmerly et al. 1995a). Again, accurate intron-exon sequences were confirmed by RT-PCR (not shown).

Figure $9 \mathrm{~B}$ shows that reconstitution could also be carried out with the full-length intron RNA or with a modified form of the $\triangle O R F$ intron that contains a $\operatorname{kan}^{\mathrm{R}}$ gene inserted in the loop of domain IV in place of the LtrA ORF. The domain IV loop region was presumed to be a desirable site for the insertion of additional genetic information, because this region normally contains the ORF and is not part of the catalytic core Jarrell et al. 1988). The modified intron reverse spliced into the DN A target site, and although the efficiency of the reaction was lower than with the shorter pLI2- 0 ORF intron, a product of the correct size was obtained (Fig. 9B). Further, cloning and sequencing via RT-PCR confirmed that the insertion had occurred at the correct position (not shown). These findings show that a group II intron can accommodate new genetic information and introduce it at a defined site in double-stranded DNA.

\section{Discussion}

Our results show that the L. Iactis LI.ItrB group II intron and its encoded protein (LtrA) can be expressed efficiently in E. coli. The LtrA protein, like the yeast al 1 and al 2 proteins, has RT, maturase, and DNA endonuclease activities. Further, as found for the mobile yeast group II introns, the Lactococcal intron endonuclease, which site-specifical ly cleaves DN A at the intron insertion site, 


\section{A 5' Sense-Enda.}
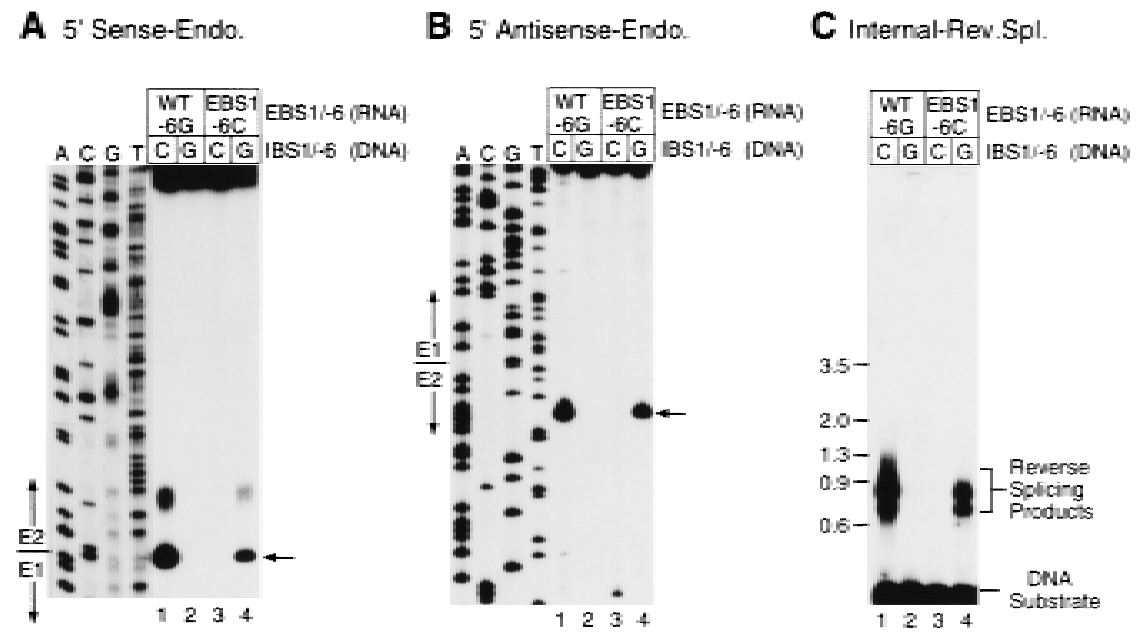

D

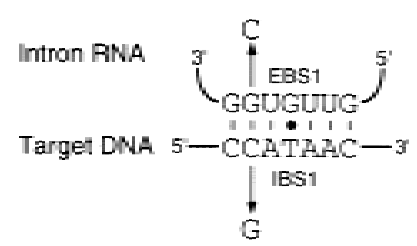

is an RN P complex containing the intron-encoded protein and the intron RNA, and the intron RNA cleaves the sense-strand of the reci pient DN A by a reverse spl icing reaction, whereas the intron-encoded protein cleaves the antisense strand. A minor difference is that antisense-strand cleavage by the Lactococcal endonuclease occurs after position +9 , compared with +10 for the yeast introns. Our results establish the general ity of the reaction mechanisms used by the yeast mtDN A introns. The finding that a bacterial group II intron has the same spectrum of activities as the yeast introns predicts that the Lactococcus intron will be mobile in Lactococcus and possibly in E. coli. The yield of active LtrA protein $(>0.1-$ $0.5 \mathrm{mg} / \mathrm{liter}$ ) is suitable for a wide variety of structural and mechanistic studies.

The active LtrA protein is recovered in RN P particle preparations, in which it appears to be associated both with unspliced precursor RN A, as expected for its role in RNA splicing, and with the excised intron RNA, in which it forms an integral component of the DNA endonuclease. The finding that RT activity with endogenous RN A templates is greatly stimulated by addition of DNA oligonucleotide primers complementary to the $3^{\prime}$ exon, but not by primers complementary to the $5^{\prime}$ exon or the $a m p^{R}$ gene of the vector, suggests that the LtrA protein may be bound specifically near the $3^{\prime}$ end of the unspliced intron. This behavior is similar to that of the yeast al $2 \mathrm{RT}$, which al so initiates reverse transcription just downstream of the intron in the $3^{\prime}$ exon of unspliced precursor RN A (Kennell et al. 1993; S. Zimmerly and A.M. Lambowitz, unpubl.).
Figure 8. Modifiable specificity of the LI.ItrB endonuclease and reverse splicing activity. $(A, B)$ Endonuclease assays with DNA substrates labeled at the $5^{\prime}$ ends of the sense and antisense strands, respectively. RN P particles from cells grown at $37^{\circ} \mathrm{C}$ expressing pLI1 (WT; lanes 1,2 ) or pLI1-EBS1-6C (lanes 3,4) were incubated with either the wild-type E1E2 DN A substrate (lanes 1,3 ) or a modified DNA substrate having a $\mathrm{C} \rightarrow \mathrm{G}$ change at E1-6 (E1$6 \mathrm{G}$; Ianes 2,4$)$. The products were analyzed in a denaturing $6 \%$ polyacrylamide gel, which was dried and autoradiographed. The diffuse bands above the major sense strand cleavage product are presumably an artifact of the $5^{\prime}$-labeled substrate, as in Fig. 6. (C) Reverse splicing assays. The RN P particles were incubated as above with internally labeled DNA substrates, and the products were denatured with glyoxal and analyzed in a 1\% agarose gel. Numbers to the left indicate DNA size markers (kb). (D) EBS1/IBS1 interactions for wild-type and modified forms of the LI.ItrB intron and DNA target sites. Watson-Crick and G-T pairings are indicated by short vertical bars and a dot, respectively.
Significantly, the correct folding of the LtrA protein appears to be facilitated by binding to the unspliced precursor or intron RNA. In the construct pLIIP, which is missing exon 1 and the $5^{\prime}$ segment of the intron, the LtrA protein was expressed, but had decreased, unstable RT activity and was less soluble than the protein expressed from pLI1, which contains the full-length intron and flanking exons. An anal ogous requirement for coexpression of an RN A-binding site was found previously for the hepatitis B virus RT (Wang et al. 1994). Because the LtrA protein remains active in RNA splicing when released from the endogenous RNA by MN ase-digestion (see be low), it appears that the RN A serves in part as a chaperone, which promotes folding of the LtrA protein into an active conformation, but is not required after folding has been achieved. We note, however, that some proportion of the LtrA protein appears to fold correctly, even in the absence of intact intron RNA. Coexpression of the intron RN A may be key for expression of fully active group II intron-encoded and related RT proteins.

The RN P particle preparations provide a source of active LtrA protein for biochemical analysis. We show here that the LtrA protein released from RNP particles by $\mathrm{MN}$ ase-digestion promotes splicing of the LI.ItrB intron under low salt conditions, the first biochemical demonstration of the maturase activity of a group II intronencoded protein. This activity does not require exogenous ATP and presumably reflects that binding of the protein to the intron RNA promotes or stabilizes the formation of the catalytical ly active RN A structure. The ability of the LtrA protein to promote splicing is readily 


\section{A}

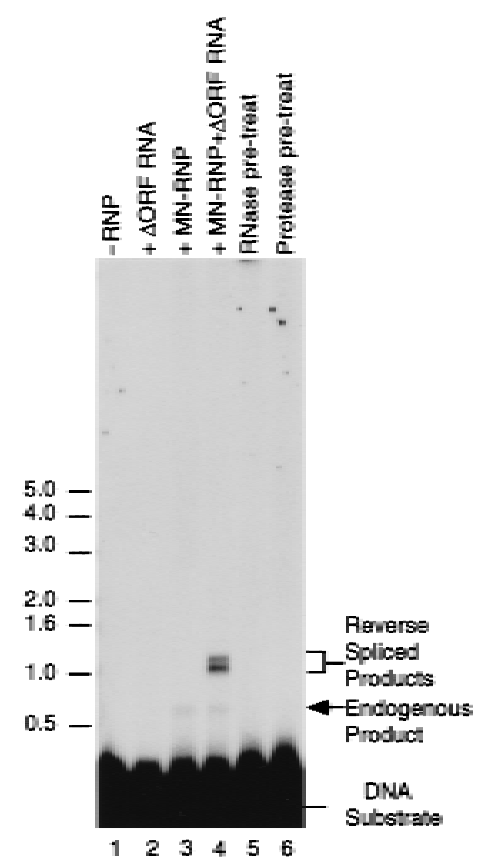

B

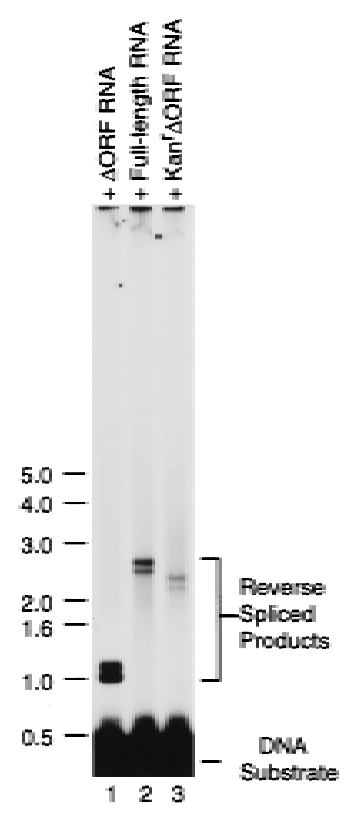

Figure 9. Reconstitution of LI.ItrB intron endonuclease activity. (A) Reconstitution and sensitivity to pretreatment with RN ase and protease. The endonuclease was reconstituted with spliced pLI2- $\triangle$ ORF /BamHI RNA and MNase-digested RNP particles and used for reverse splicing assays with internally labeled E1E2 DNA substrate ( $\sim 30$ fmoles). (Lane 1$)$ DNA substrate incubated without RN P particles; (lane 2) DNA substrate incubated with in vitro-spliced pLI2- $\mathrm{OORF}$ RN A alone; (lane 3) DNA substrate incubated with $\mathrm{MN}$ ase-digested RN $\mathrm{P}$ particles al one; (lane 4) DNA substrate incubated with endonuclease reconstituted by mixing $M N$ ase-digested RNP particles with in vitro spliced pLI2- $\Delta$ ORF RN A; (lanes 5,6) reconstituted endonuclease preincubated with $\mathrm{RN}$ ase or proteinase $\mathrm{K}$ prior to the reverse splicing reaction (see $M$ ethods). Reverse-spliced products were denatured with glyoxal and analyzed in a 1\% agarose gel. N umbers to the left indicate size markers. (B) Reconstitution with full-length and modified intron RNAs. Reverse splicing into the E1E2 DNA substrate ( 60 fmoles) was carried out with endonucleases reconstituted with the following in vitro spliced RN As: (Lane 1) pLI2- $\Delta$ ORF; (lane 2) pLI1; (lane 3) pLI2$\Delta$ ORFkan $^{\mathrm{R}}$. The products were analyzed as above.

detected in $\mathrm{E}$. coli and should be amenable to genetic analysis. The protein-dependent in vitro and in vivo splicing systems should permit detailed analysis of the maturase activity of a group II intron-encoded protein.

The site-specific endonuclease activity can be obtained either by coexpression of the LtrA protein and intron RNA or by reconstitution of LtrA protein from RNP particle preparations with in vitro-synthesized intron RN A. Interestingly, the RNP particles synthesized in $\mathrm{E}$. coli remain active in reverse splicing into the DN A target site despite degradation of the intron RN A, which, judged by the sizes of RNA fragments, appears to be cleaved in the loop of domain IV. These cleavages appar- ently leave 5' and 3' RN A halves that remain associated to form an active catalytic core. The situation is analogous to trans-spliced group II introns that are split in domain IV and reconstitute the catalytic core from separate 5' and '3' halves (Jarrell et al. 1988; Bonen 1993; $\mathrm{Michel}$ and Ferat 1995). The specific cl eavages in domain IV of the LI.ItrB intron presumably reflect its accessibility to E. coli nucleases, whereas the catalytic core may be protected either by RNA structure or bound protein.

The reconstitution approach with LI.ItrB intron RNA synthesized in vitro yields endonucl ease with intact intron RN A. Furthermore, the reconstitution experiments show that it is possible to insert additional genetic information, a 1.3-kb kan ${ }^{R}$ cassette, in domain IV, while retaining functionality of the intron RN A. Although the length of additional sequences that can be inserted in domain IV is not known, it could, in principle, be quite large in view of the finding that the trans-spliced group II introns reconstitute the catalytic core from $5^{\prime}$ and $3^{\prime}$ RNA halves synthesized at distant sites in the genome (Bonen 1993; Michel and Ferat 1995).

Group II introns are potentially useful for targeting insertion of foreign sequences at selected sites. In the case of the yeast group II introns, both the RNA and protein components contribute to the recognition of the DN A target site, and the target specificity can be modified by changing the EBS2, EBS1, or $\delta$ sequences in the intron RNA (Guo et al. 1997). We show here that a similar specificity change can be effected by modifying the EBS1 sequence in the Lactococcal intron. Further, we show that the endonucl ease reconstituted with an intron RN A containing an inserted kan $^{\mathrm{R}}$ genetic marker undergoes reverse splicing, resulting in the insertion of the $\mathrm{kan}^{\mathrm{R}}$ marker into the DN A target site. These methods based on the $\mathrm{E}$. coli genetic system therefore hold great promise for the development of group II introns that target specific foreign sequences to a desired site in DNA.

\section{Materials and methods}

E. coli strains

E. coli strains used for the expression of the LI.ItrB intron were BL21(DE3)lon-ompT (Studier and Moffatt 1986) and BLR(DE3)l on-ompT-recA::T n10(T c ${ }^{R}$ ) (N ovagen, M adison, WI). Both strains contain the DE3 prophage for the synthesis of phage T7 RNA polymerase. The strains were grown in LB or SOB medium (Sambrook et al. 1989). Antibiotics were added: $100 \mu \mathrm{g} / \mathrm{ml}$ of ampicillin; $25 \mu \mathrm{g} / \mathrm{ml}$ of chloramphenicol; $25 \mu \mathrm{g} /$ $\mathrm{ml}$ of tetracycline.

\section{Oligonucleotides}

Oligonucleotides used in this study were $5^{\prime}$ exon, $5^{\prime}$-GTTATGGATGTGTTCACGATCGACGTGGG; 3'exon, 5'-CGGAATTCCCAGTATAAAGATTCGTAGAA; amp, 5'-AGTTGCCTGACTCCCCGTCG; ex2, 5'-TTGGGATCCTCATAA GCTTTGCCGC; expr, 5'-AAAACCTCCATATGAAACCAACAATG; KS, 5'-TCGAGGTCGACGGTATC; LtrB-35, 5'-CGGGATCCTTGCAACCCACGTCGATCGTG; N-LtrA, 5'-CAAA GGATCCGATGAAACCAACAATGGCAA; N delLTR5, 5'AGTGGCTTCCATATGCTTGGTCATCACCTCATC; $\mathrm{N}$ de 
ILTR3, 5'-GGTAGAACCATATGAAATTCCTCCTCCCTAA TCAATTTT; primer 1, 5'-CCGTGCTCTGTTCCCGTATC AGC; primer 2, 5'-CTTTAGGAATGACTTTCCAGTC; primer 3, 5'-AAGCTTAGAGAAAAATAATGCGGTGC; primer 4, 5'CTTTAGGAATGACTTTCCAGTC; probe A, 5'-AAAAATGATATGGTGAAGTAGGGA; probe $B$, 5'-AAAAATGATA TGGTTATGGATGTG; SK， 5'-CGCTCTAGAACTAGTGG ATC; Ssch2, 5'-TTGCAACCCACGTCGATCGTGAACACAT CGATAACCATATCATTTTTAATTCTACGAATCTTTATACTGG.

\section{Recombinant plasmids}

Plasmids in the pLI1 series are derivatives of pET-11a (Studier et al. 1990). pLII contains the LI.ItrB intron and flanking exons cloned downstream of the phage T 7 promoter in pET-11a. The plasmid was constructed by blunt-end ligation of the 2.8-kb HindlII fragment of pLE12 (Mills et al. 1996) into the Xbal site of pET-11a (N ovagen), after filling in the 5 ' overhangs with Klenow polymerase (Life Technologies, Gaithersburg, MD).

pLIIP contains the LtrA ORF cloned directly downstream of the phage T7 promoter in pET-11a. To construct this plasmid, the LtrA ORF of pLE12 was amplified by PCR with the primers expr and ex2. The PCR product was digested with Ndel and $\mathrm{BamHI}$ and cloned between the corresponding sites of pET-11a. To ensure that no unintended changes were introduced via PCR, the 2.4-kb Sspl fragment, which includes most of the LtrA ORF, was replaced with that from pLII, and the remaining 147nucleotide region of the ORF between the ATG and Sspl site was sequenced.

pLI I-N His has $\mathrm{His}_{6}$ and Xpress (DLYDDDDK) epitope tags at the amino terminus of the LtrA ORF. To construct this plasmid, the ORF and $3^{\prime}$ exon of pLE12 were amplified by PCR with the primers N-LtrA and ex2. The PCR product was digested with BamHI, gel-purified, and cloned into the BamHI site of pRSET B (Invitrogen, San Diego, CA) to generate the intermediate plasmid plnt-N. In the second step, a region of pLE12 extending from the $5^{\prime}$ exon to the initiation codon of the LtrA ORF was amplified by PCR with the primers N delLTR5 and N delLTR3. The PCR product was cleaved with $\mathrm{Ndel}$, gel purified, and cloned in the $\mathrm{N}$ del site of plnt-N. Transformants were screened to identify a clone containing the insert in the correct orientation. To ensure that no unintended changes were introduced by PCR, the 2.4-kb Sspl fragment was replaced with that of pLI1, and the remaining region was sequenced as described above for pLIIP.

pLI1-FS is a derivative of pLI1, which has a frameshift after codon 124 of the LtrA ORF, introduced by linearizing pLI1 at the Agel site in the LtrA ORF and religating after filling in the 4-nucleotide $5^{\prime}$ overhangs with Klenow DNA polymerase (Life Technologies). pLI1-DD ${ }^{-}$and pLI1-EBS1-6C are derivatives of $\mathrm{pLI} 1$ that were constructed by PCR mutagenesis. pLII-DD ${ }^{-}$has the conserved YADD sequence in the RT domain changed to YAAA, and pLI1-EBS1-6C has a single nucleotide change in EBS1 (G284C) and a complementary change in IBS1 (E1-6G) to permit splicing. In each case, the region generated by PCR was sequenced completely to insure that no adventitious mutations had been introduced.

Plasmids in the $\mathrm{pLI} 2$ series are derivatives of $\mathrm{pBSIIKS+(Strata-}$ gene, La Jolla, CA ). pLI2 contains the 2.8-kb LI.ItrB HindIII fragment cloned into the HindlII site of pBSIIKS+ (Stratagene) in transcriptional al ignment with the phage $\mathrm{T} 3$ and lac promoters.

pLI2- $\triangle$ ORF, which has a large del etion in the intron ORF, was derived from $\mathrm{PLI} 2$ by inverse PCR, such that amino acids 40 572 of LtrA were replaced with the amino acids TR, and an Mlul site was created at the deletion joint.
pLI2- - ORFkan $^{\mathrm{R}}$ was constructed by blunt-end ligation of the 1.3-kb Sall fragment containing the $\mathrm{kan}^{\mathrm{R}}$ gene from pUC4K (Pharmacia, Piscataway, NJ) into the Mlul site of pLI2- $\Delta O R F$, after filling in both the $5^{\prime}$ overhangs with Klenow polymerase (Life Technologies).

pLHS, which was used to synthesize DNA target sites for endonuclease and reverse splicing assays, contains a 70-nucleotide sequence of ligated ItrB exons 1 and 2, extending from 35 nucleotides upstream to 35 nucleotides downstream of the intron insertion site, cloned between BamHI and EcoRI sites of pBSKS+(Stratagene). The insert was generated from pLtrBH (D. Mills and G.M. Dunny, unpubl.) by PCR with the primers LtrB35 and $3^{\prime}$ exon. pLHS-IBS1-6G, which has a $C \rightarrow G$ change at E1-6, was constructed similarly to pLHS, except that the DNA template was the 70-mer Ssch2.

\section{Expression of LtrA protein}

On the basis of optimization experiments with pLI1-N His, the following protocol was adopted for expression of the LtrA protein in E. coli. E. coli strains BL21(DE3) or BLR(DE3) were transformed with the expression plasmid, and single colonies were sel ected on LB plates containing the appropriate antibiotics. For starter cultures, the single colonies were inoculated into $2 \mathrm{ml}$ of LB medium containing antibiotics, and the cultures were shaken at $300 \mathrm{rpm}$ at $37^{\circ} \mathrm{C}$ overnight. One milliliter of the overnight culture was then inoculated into $100 \mathrm{ml}$ of LB medium containing antibiotics in a 500-ml Ehrlenmeyer flask and grown at $37^{\circ} \mathrm{C}$ in a rotary shaker $(300 \mathrm{rpm})$ for $2-4 \mathrm{hr}$, until $\mathrm{OD}_{595}$ was 0.4-0.8. For induction, IPTG was added to a final concentration of $1 \mathrm{~mm}$, and the incubation was continued for $3 \mathrm{hr}$. After induction, cells were collected by centrifugation in a Beckman JA-14 rotor ( $2200 \mathrm{~g}$ for $5 \mathrm{~min}$ at $4^{\circ} \mathrm{C}$ ), and washed with $25 \mathrm{ml}$ of ice-cold $150 \mathrm{~mm} \mathrm{~N} \mathrm{aCl}$. The washed cell pellet was resuspended in $4 \mathrm{ml}$ of ice-cold buffer A [50 mM Tris- $\mathrm{HCl}$ at pH 7.5, $1 \mathrm{~mm}$ EDTA, $1 \mathrm{~mm}$ DTT, 10\% (vol/vol) glycerol], and lysozyme (Sigma, St. Louis, MO) was added to a final concentration of 2 $\mathrm{mg} / \mathrm{ml}$. The cells were then lysed by three cycles of freezethawing between $-70^{\circ} \mathrm{C}$ and $37^{\circ} \mathrm{C}$, followed by addition of 4 volumes of HKCTD (500 mM KCl, $50 \mathrm{~mm} \mathrm{CaCl} 2,25 \mathrm{~mm}$ Tris$\mathrm{HCl}$ at $\mathrm{pH} 7.5,5 \mathrm{~mm}$ DTT) and sonication for $5 \mathrm{sec}$ or until the mixture was no longer viscous.

\section{Preparation of RNP particles}

To prepare RN P particles, $5 \mathrm{ml}$ of the $\mathrm{E}$. coli lysate, which had been centrifuged in a Beckman JA-20 rotor $(14,000 \mathrm{~g}$ for $15 \mathrm{~min}$ at $4^{\circ} \mathrm{C}$ ) to remove insoluble material, was layered over $5 \mathrm{ml}$ of $1.85 \mathrm{M}$ sucrose containing HKCTD and centrifuged in a Beckman Ti50 rotor $\left(50,000 \mathrm{~g}\right.$ for $17 \mathrm{hr}$ at $\left.4^{\circ} \mathrm{C}\right)$. The resulting RN P pellet was washed with $1 \mathrm{ml}$ of ice-cold distilled water and then dissolved in $25 \mu \mathrm{l}$ of ice-cold $10 \mathrm{~mm}$ Tris- $\mathrm{HCl}$ at $\mathrm{pH} 8.0$, and 1 mM DTT. After removal of insoluble material in a microcentrifuge $\left(15,000 \mathrm{~g}\right.$ for $5 \mathrm{~min}$ at $\left.4^{\circ} \mathrm{C}\right)$, the RN Ps were stored frozen at $-70^{\circ} \mathrm{C}$. The yield of RN P particles was $25-50 \mathrm{OD}_{260}$ units per $100 \mathrm{ml}$ of culture, with $1 \mathrm{OD}_{260}$ unit of RN Ps containing 0.3-3 $\mu \mathrm{g}$ of LtrA protein. For in vitro splicing or reconstitution experiments, to minimize nuclease activity, the RN Ps were further purified by an additional centrifugation through a $1.85 \mathrm{M}$ sucrose cushion, as described above.

\section{RT assays}

RT activity with poly(rA)-oligo(dT) $)_{18}$ was assayed in $10 \mu \mathrm{l}$ of reaction medium containing $10 \mathrm{mM} \mathrm{KCl}, 10 \mathrm{mM} \mathrm{M} \mathrm{gCl} 2,50 \mathrm{~mm}$ Tris- $\mathrm{HCl}$ at $\mathrm{pH} 7.5,5 \mathrm{~mm}$ DTT, $0.025 \mathrm{OD}_{260}$ units of RNP 
particles, $1 \mu \mathrm{g}$ of poly(rA)-oligo(dT) ${ }_{18}, 10 \mu \mathrm{Ci}$ of $\left[\alpha^{-}{ }^{32} \mathrm{P}\right] \mathrm{dTTP}$ (3000 Ci/mmole; DuPont-N ew England Nuclear), and $1 \mu \mathrm{g}$ of RN ase $A$ (Sigma), as described for the yeast al 2 intron (M oran et al. 1995). The products were spotted on a DE81 filter (Whatman, Fairfield, $\mathrm{NJ}$ ), which was processed and counted for Cerenkov radioactivity. In contrast to the yeast intron, where $\mathrm{RN}$ ase $\mathrm{A}$ is necessary to release the RT from endogenous RNA templates (M oran et al. 1995; S. Zimmerly and A.M. Lambowitz, unpubl.), the RN P particle preparations containing the LtrA protein had essentially the same RT activity in the presence or absence of RN ase A (not shown). The RT activity with the artificial template was optimal at $0-25 \mathrm{~mm} \mathrm{KCl}$ and 5-10 $\mathrm{mm} \mathrm{M} \mathrm{g}^{2+}$ and was strongly inhibited at higher salt concentrations.

Endogenous reverse transcription reactions were carried out in $10 \mu \mathrm{l}$ of reaction medium containing $10 \mathrm{~mm} \mathrm{KCl}, 10 \mathrm{~mm}$ $\mathrm{MgCl}_{2}, 50 \mathrm{~mm}$ Tris- $\mathrm{HCl}$ at $\mathrm{pH} 7.5,5 \mathrm{~mm}$ DTT, $0.025 \mathrm{OD}_{260}$ units of RN P particles, $200 \mu \mathrm{M}$ each of dATP, dCTP, and dGTP, and $10 \mu \mathrm{Ci}$ of $\left[\alpha^{-32} \mathrm{P}\right] \mathrm{dTTP}(3000 \mathrm{Ci} / \mathrm{mmole}$; DuPont-N ew England N ucl ear). In some cases, a synthetic DN A ol igonucleotide primer (20 pmoles) complementary to endogenous RN A was added to the reactions (see Fig. 2). Reactions were initiated by addition of the RN P particles, incubated for $10 \mathrm{~min}$ at $37^{\circ} \mathrm{C}$, and assayed for incorporation of [ $\left.{ }^{32} \mathrm{P}\right]-d T T P$ into high molecular weight material by spotting on a DE81 filter, as described above for exogenous substrate assays. RT activity with endogenous RNA templates was optimal at $0-50 \mathrm{~mm} \mathrm{KCl}$ and $5-20 \mathrm{~mm}$ $\mathrm{MgCl}_{2}$.

\section{Analysis of in vivo splicing products}

Total cellular RNA was isolated from E. coli BL21(DE3) containing the indicated plasmids. Cells were grown in TBYE (1.0\% tryptone, $0.5 \% \mathrm{~N} \mathrm{aCl}, 0.1 \%$ yeast extract) with ampicillin to an $\mathrm{OD}_{650}$ of 0.2 and induced with $1 \mathrm{~mm}$ IPTG. RN A was extracted by the lysozyme freeze-thaw method, followed by phenol extraction and ethanol precipitation (Belfort et al. 1990).

For N orthern hybridizations, total cellular RNA (15 $\mu \mathrm{g})$ was separated in a $1.5 \%$ agarose/2.2 $\mathrm{M}$ formal dehyde gel in $10 \mathrm{~mm}$ sodium phosphate ( $\mathrm{pH}$ 6.5) running buffer and blotted to a Hybond $\mathrm{N}$ membrane (Amersham, Arlington Heights, IL), as described (Sambrook et al . 1989). The RN A was cross-linked to the membrane with a UV Stratal inker 2400 (Stratagene) under autocross-link conditions. Blots were hybridized in Rapid-hyb buffer (Amersham) for $2 \mathrm{hr}$ at $45^{\circ} \mathrm{C}$ with $5^{\prime}{ }^{32} \mathrm{P}$-labeled DNA oligonucleotide probes.

For primer extension analysis, each reaction contained $5 \mu \mathrm{g}$ of cellular RNA in $62.5 \mathrm{~mm}$ Tris- $\mathrm{HCl}$ at $\mathrm{pH} 8.0,75 \mathrm{~mm} \mathrm{NaCl}, 12.5$ mM DTT with 0.2 pmole of $5^{\prime}{ }^{32} \mathrm{P}$-labeled primers. Samples were incubated at $60^{\circ} \mathrm{C}$ for $3 \mathrm{~min}$ and placed on ice. Buffer containing $50 \mathrm{~mm}$ Tris $-\mathrm{HCl}$ at $\mathrm{pH} 8.0,60 \mathrm{~mm} \mathrm{NaCl}, 10 \mathrm{~mm}$ DTT, $6 \mathrm{~mm}$ M gOAc, $0.47 \mathrm{~mm}$ each dNTP, and 3 units of AMV RT (Life Technologies) was added, and the samples were incubated at $48^{\circ} \mathrm{C}$ for $30 \mathrm{~min}$. The reaction was stopped by adding formamide-dye mix (Belfort et al. 1990). Samples were heated to $95^{\circ} \mathrm{C}$ for 3 min before loading on a 10\% polyacrylamide (19:1)/ $7 \mathrm{~m}$ urea gel. DNA sequencing ladders generated with primers 1 and 2 were run in parallel lanes.

\section{In vitro splicing}

Protein-assisted splicing reactions were carried out with $\mathrm{MN}$ ase-digested RN P particles purified through two ultracentrifugation cycles (see above). After decanting the supernatant and washing the tube walls with ice-cold distilled water, the final RNP pellet was dissolved in $25-100 \mu \mathrm{l}$ of $10 \mathrm{~mm}$ Tris- $\mathrm{HCl}$ at $\mathrm{pH} 8.0,1 \mathrm{~mm}$ DTT to a concentration of 0.1 to $0.2 \mathrm{OD}_{260}$ units/ $\mu$ l. For $\mathrm{MN}$ ase digestion, an equal volume of $40 \mathrm{~mm}$ Tris$\mathrm{HCl}$ at $\mathrm{pH}$ 7.5, $10 \mathrm{~mm} \mathrm{CaCl}$, $20 \mathrm{~mm}$ DTT was added. Digestion with M N ase (15 units; Pharmacia) was carried out for $10 \mathrm{~min}$ at $22^{\circ} \mathrm{C}$ and then terminated by addition of $10 \mathrm{~mm}$ EGTA.

Substrates for in vitro splicing were ${ }^{32} \mathrm{P}$-labeled in vitro transcripts synthesized with phage T 3 RN A polymerase (Stratagene) from pLI2- $\triangle$ ORF linearized with EcoRI. In vitro transcription was in $50 \mu$ l of reaction medium (Caprara et al. 1996) containing $1 \mu \mathrm{g}$ of template DN A, $0.5 \mathrm{~mm}$ each of ATP, GTP, CTP, $0.4 \mathrm{~mm}$ UTP, and $5 \mu \mathrm{Ci}\left[\alpha{ }^{32} \mathrm{P}\right]-U T P(3000 \mathrm{Ci} / \mathrm{mmole})$ for $2 \mathrm{hr}$ at $37^{\circ} \mathrm{C}$. The DN A template was digested with DN ase I (Pharmacia; 10 units for $20 \mathrm{~min}$ at $37^{\circ} \mathrm{C}$ ), and the precursor RNA was purified in a denaturing $4 \%$ polyacrylamide gel.

For splicing reactions, the ${ }^{32} \mathrm{P}$-labeled precursor RN A (16 nM; $\sim 100,000 \mathrm{cpm}$ ) was dissolved in $10 \mu \mathrm{l}$ of low salt reaction medium containing $100 \mathrm{~mm} \mathrm{~N} \mathrm{aCl}, 10 \mathrm{~mm} \mathrm{M} \mathrm{gCl} 2,40 \mathrm{~mm}$ Tris- $\mathrm{HCl}$ at $\mathrm{pH}$ 7.5, $10 \mathrm{~mm} \mathrm{DTT}$, and 2 units of RN asin (Amersham), then incubated at $65^{\circ} \mathrm{C}$ for $1 \mathrm{~min}$ and slowly cooled to $37^{\circ} \mathrm{C}$ in a waterbath. After addition of $1 \mu \mathrm{g}$ of E. coli tRN A (Sigma) carrier as protection against nonspecific nucleases, splicing reactions were initiated by addition of the M N ase-treated RN P particles $\left(0.1 \mathrm{OD}_{260}\right.$ units), incubated at $37^{\circ} \mathrm{C}$ for different times (see Fig. 5), and terminated by addition of EDTA to a final concentration of $15 \mathrm{~mm}$. The products were incubated with proteinase $\mathrm{K}$ (Sigma; $1 \mu \mathrm{g}$ for $5 \mathrm{~min}$ at $25^{\circ} \mathrm{C}$ ), extracted with phenol-chloroform-isoamyl alcohol (25:24:1), ethanol precipitated, and analyzed in a denaturing $4 \%$ polyacrylamide gel. Self-splicing reactions were carried out similarly in high salt (HS) reaction medium containing $500 \mathrm{mM} \mathrm{N} \mathrm{H}_{4} \mathrm{Cl}, 50 \mathrm{~mm} \mathrm{MgCl} 2,50 \mathrm{~mm}$ Tris$\mathrm{HCl}$ at $\mathrm{pH} 7.5,10 \mathrm{~mm}$ DTT, 2 units of RN asin, and $1 \mu \mathrm{g}$ of E. coli tRN A (Sigma) carrier, and terminated by addition of EDTA to a final concentration of $75 \mathrm{~mm}$.

\section{Preparation of DNA substrates for reverse splicing and} endonuclease reactions

For most experiments, 129-bp internally or 5' end-label ed DN A substrates containing the junction of exons 1 and 2 of the ItrB gene were synthesized from pLHS by PCR with primers KS and SK, by use of procedures described previously (Zimmerly et al. 1995b; Yang et al. 1996). The DN A substrates were purified in a $6 \%$ nondenaturing polyacrylamide gel.

For the experiment of Figure 7B, DNA substrates labeled at the $5^{\prime}$ end of the sense or antisense strands were prepared from pLHS linearized at the Notl or Xhol sites, respectively. The digested plasmids were dephoshorylated with calf intestine alkaline phosphatase (Boehringer Mannheim, Indianapolis, IN), 5 '-end-labeled with phage T4 polynucleotide kinase ( $\mathrm{N}$ ew England Biolabs, Beverly, MA) and [ $\gamma^{-32}$ P]ATP (3000 Ci/mmole; DuPont-N ew England N uclear) (Sambrook et al. 1989), and redigested with Kpnl or Sacl for the sense and antisense strand substrates, respectively. DN A substrates labeled at the $3^{\prime}$ end of the sense or antisense strands were prepared by digesting pLHS with Kpnl or Sacl, respectively. The digested plasmids were 3 '-end-labeled with terminal deoxynucleotidyl transferase (TdT) (Life Technologies) and $\left[\alpha^{-}{ }^{32} \mathrm{P}\right] \mathrm{dGTP}(3000 \mathrm{Ci} / \mathrm{mmole}$; Dupont-N ew England Nuclear) (Collins and Hunsaker 1985), and then digested with $\mathrm{N}$ otl or $\mathrm{Xhol}$ for the sense and antisense strand DN A substrates, respectively. The 5 ' - and 3 '-end-label ed DNA substrates (Notl-Kpnl; 144 bp, Xhol-Sacl; 145 bp) were purified in a $2 \%$ agarose gel.

\section{DNA endonuclease and reverse splicing assays}

DNA endonuclease and reverse splicing assays were essentially as described for the yeast al 1 and al 2 introns (Zimmerly et al. 
1995a,b; Yang et al. 1996), except that the reaction medium (10 $\mathrm{mm} \mathrm{KCl}, 10 \mathrm{~mm} \mathrm{MgCl}, 50 \mathrm{~mm}$ Tris- $\mathrm{HCl}$ at $\mathrm{pH} 7.5$, and $5 \mathrm{~mm}$ DTT) was optimized for the LI.ItrB intron. Unless specified otherwise, $150,000 \mathrm{cpm}$ of the DNA substrate $\left(-125\right.$ fmoles of $5^{\prime}-$ end-labeled substrate or $\sim 30$ fmoles of internally-labeled substrate) were used per reaction. RNP particles were tested for sensitivity to pretreatment with RN ase $A$ or proteinase $K$, and reaction products were tested for sensitivity to nucleases, as described (Zimmerly et al. 1995a,b). Alkali treatment of reaction products was carried out in $50 \mu \mathrm{l}$ of $0.2 \mathrm{~N} \mathrm{~N} \mathrm{aOH}$ and $2 \mathrm{~mm}$ EDTA for $5 \mathrm{~min}$ at $95^{\circ} \mathrm{C}$.

Reconstitution of the Lactococcus intron endonuclease with LtrA protein and in vitro-synthesized intron RNA

The RNA component for reconstitution was generated by in vitro transcription of pLI2- $\Delta$ ORF, pLI2- $\Delta$ ORFkan, or pLI1. The plasmids were linearized with BamHI and transcribed with phage T 3 or T 7 RN A polymerases (Caprara et al. 1996). To generate the intron RNA for reconstitution, the in vitro transcript (30-50 $\mu \mathrm{g}$ ) was self-spliced for $60 \mathrm{~min}$ at $37^{\circ} \mathrm{C}$ in $100 \mu \mathrm{l}$ of $1 \mathrm{M}$ $\mathrm{NH}_{4} \mathrm{Cl}, 100 \mathrm{~mm} \mathrm{M} \mathrm{gCl} 2,50 \mathrm{~mm}$ Tris- $\mathrm{HCl}$ at $\mathrm{pH}$ 7.5. Prior to reconstitution, the RNA was heated to $85-90^{\circ} \mathrm{C}$ for $2 \mathrm{~min}$, then stored on ice. The protein fraction for reconstitution was prepared by $\mathrm{MN}$ ase digestion of purified RN P particles containing LtrA protein expressed from pLI1. The RNP particles (1.0 $\mathrm{OD}_{260}$ ) were resuspended in $40 \mu \mathrm{l}$ of $10 \mathrm{~mm}$ Tris- $\mathrm{HCl}$ at $\mathrm{pH} 7.5$, $10 \mathrm{~mm} \mathrm{M} \mathrm{gCl}, 2.5 \mathrm{~mm} \mathrm{CaCl}, 5 \mathrm{~mm}$ DTT and incubated with $\mathrm{MN}$ ase (36 units; Pharmacia) for $10 \mathrm{~min}$ at $22^{\circ} \mathrm{C}$, after which the $\mathrm{MN}$ ase was inactivated by addition of EGTA to $7.5 \mathrm{~mm}$. For reconstitution and reverse splicing, $0.05 \mathrm{OD}_{260}$ units of the MNase-treated RNP particles was mixed with $1 \mu \mathrm{g}$ of the spliced RNA in $20 \mu \mathrm{l}$ of the standard reverse splicing reaction medium (see above) and 30 or 60 fmoles of ${ }^{32} \mathrm{P}$-labeled DNA substrate. In the experiment of Figure 9B, the mixture was preincubated on ice for $10 \mathrm{~min}$ before initiating the reverse splicing reaction by raising the temperature to $37^{\circ} \mathrm{C}$. The reconstitution mixtures were tested for sensitivity to pretreatment with $2 \mu \mathrm{g}$ of RN ase A (Sigma) plus 2.5 units of RN ase T1 (Boehringer Mannheim) or proteinase $\mathrm{K}\left(2 \mu \mathrm{g}\right.$; Sigma) for $5 \mathrm{~min}$ at $22^{\circ} \mathrm{C}$ prior to adding the DNA substrate.

\section{Acknowledgments}

We thank Michelle Simons for technical assistance, Benoit Cousineau and Michael Cusick for maturase mutants, and Richard Lease for comments on the manuscript. This work was supported by N ational Institutes of Heal th grants GM 37949 to A.M.L., GM 39422 and GM 44844 to M.B., and a grant from the Minnesota-South Dakota Dairy Research Center to G.M.D. H.W. is the recipient of an Erwin Schroedinger Postdoctoral Fellowship from the Austrian Science Foundation.

The publication costs of this article were defrayed in part by payment of page charges. This article must therefore be hereby marked "advertisement" in accordance with 18 USC section 1734 solely to indicate this fact.

\section{References}

Belfort, M., K. Ehrenman, and P.S. Chandry. 1990. Genetic and molecular analysis of RNA splicing in Escherichia coli. Methods Enzymol. 181: 521-539.

Bonen, L. 1993. Trans-splicing of pre-mRN A in plants, animals, and protists. FASEB J. 7: 40-46.

Caprara, M.G., G. Mohr, and A.M. Lambowitz. 1996. A tyrosyl-
tRNA synthetase protein induces tertiary folding of the group I intron catalytic core. J. Mol. Biol. 257: 512-531.

Carignani, G., O. Groudinsky, D. Frezza, E. Schiavon, E. Bergantino, and P. Slonimski. 1983. An mRN A maturase is encoded by the first intron of the mitochondrial gene for the subunit I of cytochrome oxidase in S. cerevisiae. Cell 35: 733-742.

Collins, M.L. and W.R. Hunsaker. 1985. Improved hybridization assays employing tailed oligonucleotide probes: A direct comparison with $5^{\prime}$-end-labeled oligonucleotide probes and nick-translated plasmid probes. Anal. Biochem. 151: 211224.

Costa, M., E. Dème, A. Jacquier, and F. Michel. 1997. Multiple tertiary interactions involving domain II of group II selfsplicing introns. J. Mol. Biol. 267: 520-536.

Curcio, M.J. and M. Belfort. 1996. Retrohoming: cDNA-mediated mobility of group II introns requires a catalytic RNA. Cell 84: 9-12.

Daniels, D., W.J. Michels, and A.M. Pyle. 1996. Two competing pathways for self-splicing by group II introns: A quantitative analysis of in vitro reaction rates and products. J. Mol. Biol. 256: 31-49.

Eskes, R., J. Yang, A.M. Lambowitz, and P.S. Perlman. 1997. Mobility of yeast mitochondrial group II introns: Engineering a new site specificity and retrohoming via full reverse splicing. Cell 88: 865-874.

Ferat, J.-L. and F. M ichel. 1993. Group II self-splicing introns in bacteria. Nature 364: 358-361.

Ferat, J.-L., M. Le Gouar, and F. M ichel. 1994. Multiple group II self-splicing introns in mobile DNA from Escherichia coli. C.R. Acad. Sci. Paris 317: 141-148.

Guo, H., S. Zimmerly, P.S. Perlman, and A.M. Lambowitz. 1997. Group II intron endonucleases use both RN A and protein subunits for recognition of specific sequences in doublestranded DNA, EMBO J. (in press).

Jarrell, A.K., R.C. Dietrich, and P.S. Perlman. 1988. Group II intron domain 5 facilitates a trans-splicing reaction. Mol. Cell. Biol. 8: 2361-2366.

Kennell, J.C., J.V. Moran, P.S. Perlman, R.A. Butow, and A.M. Lambowitz. 1993. Reverse transcriptase activity associated with maturase-encoding group II introns in yeast mitochondria. Cell 73: 133-146.

Knoop, V. and A. Brennicke. 1994. Evidence for a group II intron in Escherichia coli inserted into a highly conserved reading frame associated with mobile DN A sequences. Nucleic Acids Res. 22: 1167-1171.

Laemmli, U.K. 1970. Cleavage of structural proteins during the assembly of the head of bacteriophage T4. Nature 227: 680685.

Lambowitz, A.M. and P.S. Perlman. 1990. Involvement of aminoacyl-tRN A synthetases and other proteins in group I and group II intron splicing. Trends Biochem. Sci. 15: 440-444.

Lazowska, J., B. Meunier, and C. Macadre. 1994. Homing of a group II intron in yeast mitochondrial DNA is accompanied by unidirectional co-conversion of upstream-located markers. EMBO J. 13: 4963-4972.

Michel, F. and J.-L. Ferat. 1995. Structure and activities of group II introns. Annu. Rev. Biochem. 64: 435-461.

Mills, D., L.L. McKay, and G.M. Dunny. 1996. Splicing of a group II intron involved in the conjugative transfer of pRS01 in Lactococci. J. Bacteriol. 178: 3531-3538.

Mohr, G., P.S. Perlman, and A.M. Lambowitz. 1993. Evolutionary relationships among group II intron-encoded proteins and identification of a conserved domain that may be related to maturase function. Nucleic Acids Res. 21: 4991-4997.

Moran, J.V., K.L. Mecklenburg, P. Sass, S.M. Belcher, D. 


\section{Matsuura et al.}

Mahnke, A. Lewin, and P.S. Perlman. 1994. Splicing defective mutants of the COXI gene of yeast mitochondrial DNA: Initial definition of the maturase domain of the group II intron al2. Nucleic Acids Res. 22: 2057-2064.

M oran, J.V., S. Zimmerly, R. Eskes, J.C. Kennell, A.M. Lambowitz, R.A. Butow, and P.S. Perlman. 1995. Mobile group II introns of yeast mitochondrial DNA are novel site-specific retroelement. Mol. Cell. Biol. 15: 2828-2838.

Mullany, P., M. Pallen, M. Wilks, J.R. Stephen, and S. Tabaqchali. 1996. A group II intron in a conjugative transposon from the gram-positive bacterium, Clostridium difficile. Gene 174: 145-150.

Pyle, A.M. 1996. Inside an intron invasion. Nature 381: 280281.

Sal danha, R.J., G. M ohr, M. Belfort, and A.M . Lambowitz. 1993. Group I and group II introns. FASEB J. 7: 15-24.

Sambrook, J., E.F. Fritsch, and T. Maniatis. 1989. Molecular cloning: A laboratory manual. Cold Spring Harbor Laboratory Press, Cold Spring Harbor, N.Y.

Sharp, P.A. 1991. Five easy pieces. Science 254: 663.

Shearman, C., J. Godon, and M. Gasson. 1996. Splicing of a group II intron in a functional transfer gene of Lactococcus lactis. Mol. Microbiol. 21: 45-53.

Studier, F.W. and B.A. M offatt. 1986. Use of bacteriophage T7 RN A polymerase to direct selective high-level expression of cloned genes. J. Mol. Biol. 189: 113-130.

Studier, F.W., A.H. Rosenberg, J.J. Dunn, and J.W. Dubendorff. 1990. Use of T7 RNA polymerase to direct expression of cloned genes. Methods Enzymol. 185: 60-89.

Wang, G.H., F. Zoulim, E.H. Leber, J. Kitson, and C. Seeger. 1994. Role of RNA in enzymatic activity of the reverse transcriptase of hepatitis B viruses. J. Virol. 68: 8437-8442.

Yang, J., S. Zimmerly, P.S. Perlman, and A.M. Lambowitz. 1996. Efficient integration of an intron RN A into double-stranded DNA by reverse splicing. Nature 381: 332-335.

Zimmerly, S., H. Guo, R. Eskes, J. Yang, P.S. Perlman, and A.M. Lambowitz. 1995a. A group II intron RN A is a catalytic component of a DNA endonuclease involved in intron mobility. Cell 83: 529-583.

Zimmerly, S., H. Guo, P.S. Perlman, and A.M. Lambowitz. 1995b. Group II intron mobility occurs by target DNAprimed reverse transcription. Cell 82: 545-554. 


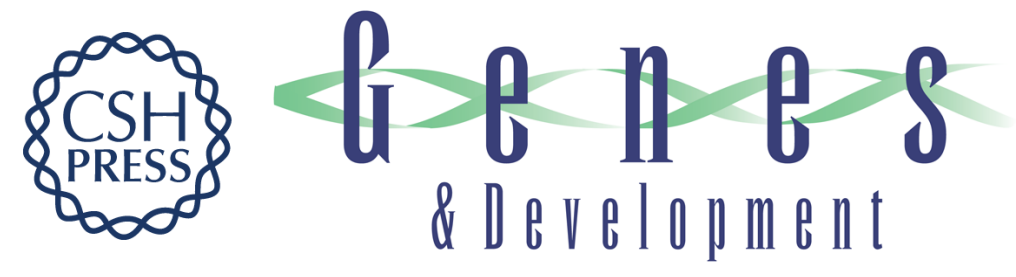

\section{A bacterial group II intron encoding reverse transcriptase, maturase, and DNA endonuclease activities: biochemical demonstration of maturase activity and insertion of new genetic information within the intron}

Manabu Matsuura, Roland Saldanha, Hongwen Ma, et al.

Genes Dev. 1997, 11:

Access the most recent version at doi:10.1101/gad.11.21.2910

References

This article cites 33 articles, 5 of which can be accessed free at:

http://genesdev.cshlp.org/content/11/21/2910.full.html\#ref-list-1

License

Email Alerting

Service

Receive free email alerts when new articles cite this article - sign up in the box at the top right corner of the article or click here.

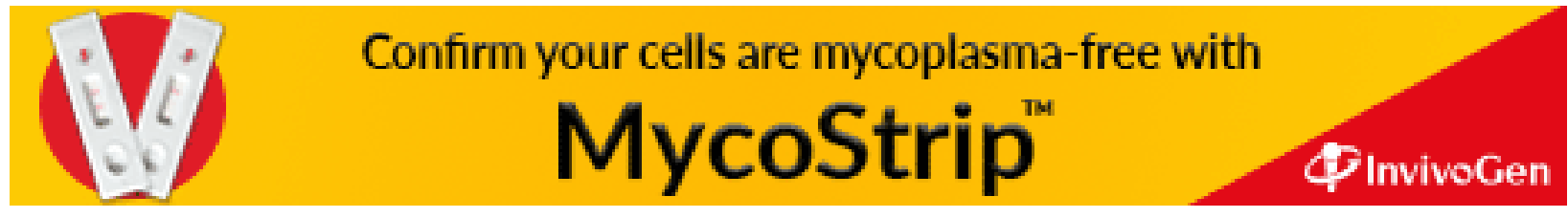

